\title{
Materiality of Minoan Writing: Modes of display and perception
}

\author{
Georgia Flouda
}

Heraklion Archaeological Museum

\begin{abstract}
Introduction
Writing helps to objectify ideas and to mediate symbols by expressing and transmitting information and meaning through its visual form, which is also constituted by its materiality. Recent cross-disciplinary studies have demonstrated that considering writing not from a purely epigraphical stance but as material practice can transform research agendas by bridging archaeology, social anthropology and cognitive semiotics. A material practice approach specifically allows us to understand the following crucial questions: how the physical substance of the writing surface helps the inscribed objects transcend space and time (Zinna 2011: 635); also, how writing technologies embody our mental trajectories by shaping writing processes (Haas 1996). These technologies carry with them an embedded history of design, which tends to become more complex with each subsequent stage of development (Schmandt-Besserat 2007). Such a discourse is novel in Minoan epigraphy, which is either concerned mainly with attempts at script decipherment or is integrated into socioeconomic studies with a focus on administrative dynamics. In these narratives, the significance of visual display as well as other types of embodied perception of Minoan writing is usually overlooked. This chapter accordingly seeks to outline a framework for exploring modes of display and the perception of the two earliest Aegean scripts that were used on $2^{\text {nd }}$-millennium вC Crete. Since Cretan Hieroglyphic and Linear A are still undeciphered, their attestations will be studied as signs in the Peircean sense, "namely something which stands to somebody for something in some respect or capacity" (Peirce 1931: 2.228). Attention will be redirected from the written form of the relevant inscriptions, the signifier or representamen (Chandler 2007: 30), to the physical aspects of their material supports and to the symbolic messages projected by them. The premise underlying such a pursuit is that material,
\end{abstract}

\section{How to cite this book chapter:}

Flouda, G. 2013. Materiality of Minoan Writing: Modes of display and perception. In: Piquette, K. E. and Whitehouse, R. D. (eds.) Writing as Material Practice: Substance, surface and medium. Pp. 143-174. London: Ubiquity Press. DOI: http://dx.doi.org/10.5334/bai.h 
size, shape and other functional aspects of the inscribed artefacts were also perceived by past actors as signifiers; these were employed and transmitted within various material and ideological contexts. For example, formal Egyptian hieroglyphic appearing on monuments may have implied a formal type of communication with the divine sphere, as opposed to the cursive hieratic version of the script (Wilson 2003: 22-23, 49-57).

In addressing the symbolic resources embodied by Minoan inscribed artefacts, I shall follow the notion that objects not only became invested with meaning through their association with people but also were themselves constitutive of meanings, behaviour and social relations (Dant 2005: 60-83; Gell 1998; Graves-Brown 2000; Knappett 2005). Meaning is formed from the individualised multi-sensorial experience of the objects and from discourse that includes performance, such as public display events, funerary ceremonies and periodically enacted rituals (Jones 2007: 42). Hence our examination of categories of artefact that bear Cretan Hieroglyphic and Linear A inscriptions will examine the symbolic connotations of these two scripts with particular attention directed the impact of the materiality of their supports on perception. Special emphasis will be given to emblematic artefacts, such as hieroglyphic sealstones - sphragistic devices inscribed with hieroglyphic signs. Moreover, the combination of script with images that may have constituted a visual code on these and on earlier seals will be discussed. In addition to hieroglyphic sealstones, metal, stone and clay objects carrying Linear A inscriptions of a non-administrative character will be considered. Semiotic relationships that are grounded in the material properties and the performative capacities of the objects themselves will also be explored, in order to detect aspects of artefactual meaning that may not be immediately obvious from a conventional perspective.

To this end, the following questions will be posed: how did the shape and size of the Cretan Hieroglyphic and Linear A inscription-carriers inform the creation of the relevant objects? Did the materials of the writing supports make possible different recording formats? Which physical and compositional parameters were pertinent to the experience of the inscriptions thereon by viewers, including elites, or by other segments of the population? In order to address the modes of perception of Minoan writing, the discussion will rely on integrational semiology, an approach that treats reading and writing as integrated and linked by "reciprocal presupposition" (Harris 1995: 6). From this perspective, the graphic symbols of the scripts are arranged in the "graphic space", namely the area where text is positioned and read (Harris 1995: 121), according to a visual logic that guides perception. This logic involves conventions whose structure can be understood as a "graphic rhetoric" (Drucker and McGann 2001: 96-98). In order to reconstruct the latter with regard to Minoan writing, I will treat directionality, alignment and scale of the Hieroglyphic and Linear A signs as indexes, and consider the ways in which these may have affected the experience of the inscribed artefacts by social actors, as well as the role of these objects in practices of remembrance.

\section{Semiotic Associations and Visual Perception in Protopalatial Hieroglyphic Writing: The interface between images and text}

\section{Introducing the Writing Systems}

The time of the earliest attestation of the two Cretan writing systems and the extent of literacy, during the period when these were established and used simultaneously (from the $18^{\text {th }}$ until the early $17^{\text {th }}$ century $\mathrm{BC}$ ), remain open-ended questions. Through analogies with the latest of the three Aegean scripts, the deciphered Linear B, we know that both Cretan Hieroglyphic and Linear A represent logo-syllabic writing systems (Bennet 2008: 5). They are formed of logograms, i.e. signs representing a word or a 'morpheme', and syllabograms, i.e. signs corresponding phonetically to syllables. The two scripts may stem from a common ancestor, which was most probably 


\begin{tabular}{|l|l|c|}
\hline \multicolumn{1}{|c|}{ Pottery Phase } & \multicolumn{1}{c|}{ Cultural Phase } & \multicolumn{1}{c|}{ Dates (BC) } \\
\hline Early Minoan (EM) I-III & Early Prepalatial & $c .3100 / 3000-2100 / 2000$ \\
\hline Middle Minoan (MM) IA & Late Prepalatial & $2100 / 2000-1925 / 1900$ \\
\hline Middle Minoan (MM) IB-II & Protopalatial & $1925 / 1900-1750 / 1720$ \\
\hline $\begin{array}{l}\text { Middle Minoan (MM) III - Late } \\
\text { Minoan (LM) IA-B }\end{array}$ & Neopalatial & $1750 / 1720-1490 / 1470$ \\
\hline
\end{tabular}

Table 1: Chronological table.

introduced at the transition to the Protopalatial period (cf. Table 1), the 'Archanes script' (Godart 1999; Olivier and Godart 1996²:31; Yule 1980: 209-210). The latter is documented by a few signs of pictorial character appearing exclusively on seals and arranged in isolation or in two standardised sign-groups. The possibility that these signs conveyed phonetic values is supported by their later occurrence within the Hieroglyphic and Linear A epigraphic corpus, as will be discussed in the following paragraphs.

The Cretan Hieroglyphic signary (Olivier and Godart 1996: 17) represents a fully developed stage of the writing system, as it was employed by Middle Minoan (hereafter MM) IIB, namely at the end of the Protopalatial period. The clay documents from the so-called Quartier $\mathrm{Mu}, \mathrm{a}$ MM IIB residential and industrial complex of buildings at Malia (Olivier and Godart 1996: 27, \#070-096), and from the MM IIB archive of the palace at Petras / Siteia (Tsipopoulou and Hallager 2010: 70-86) document the use of the script for administrative purposes in the north-central and eastern part of the island. ${ }^{3}$ At the palace of Phaistos in the Mesara plain, Hieroglyphic was used sporadically at the end of MM IIB, alongside Linear A (Militello 2000: 235; 2002: 51-52, n. 1, n. 10). However, the earliest evidence for written administration at Knossos comes from high-profile buildings close to the first palace and includes a Linear A tablet that dates by context to the MM IIA period (Schoep 2006: 47, n. 82; Schoep 2007). Hieroglyphic appears well established in the bureaucracy of the Knossian palace's West Wing at the transition to and during the early Neopalatial period (MM IIB-IIIA; cf. Olivier and Godart 1996: 28, \#001-069). At the aforementioned sites, transactions were recorded by means of various clay documents, including Hieroglyphic tablets, four-sided 'bars', 'crescents', 'medallions' and pierced labels conventionally called 'lames' (cf. Olivier and Godart 1996: passim on typology) ${ }^{4}$ or Linear A tablets (Schoep 2002a: 16). The recording of income and expenditures was also implemented with clay sealings. These were formed by pressing the clay over knotted string attached to or hanging from goods, and then impressing it with sealstones; the sealings were often also incised with inscriptions (Tsipopoulou and Hallager 2010: 12-14, fig. 1). Furthermore, notational systems documenting specific types of transactions can be deduced from the occasional use of clay documents which were not attached to goods, namely 'noduli' (cf. MacDonald 2007: fig. 4.1, nos 8, 10; Weingarten 2007: 134-136, pl. 41) and clay 'proto-roundels' (Perna 1995: 104-122).

With regard to literacy, the readers of the Hieroglyphic inscriptions have been sought among the ranks of administrators or scribes (Karnava 2000: 236). However, recent studies emphasising power structures of a heterarchical nature, such as factions or corporate groups (Schoep 2002c: 117), prompt us to rethink the use of writing in the Protopalatial polities. In particular, a hieroglyphic tablet from a MM IIB context of the extra-urban regional sanctuary at Kato Syme records agricultural commodities and, consequently, supports the presence of a literate writer or, at least, reader, in the sanctuary (Karnava 2000: 225-226, 236; Lebessi et al. 1995). This, in turn, suggests the possibility of a wider use of the Hieroglyphic script outside the strict confines of the palatial centres. Moreover, the hypothesis that different social entities at Malia had access to power resources and may have been competing for power, is supported by the occurrence of stone prismatic seals in the residential part of the town (Schoep 2002b: 19-21). These prisms were produced locally at the Seal Cutter's Workshop of Quartier Mu (Poursat 1996: 7-22, 103-110, 
149-153) and bear engraved hieroglyphic sign-groups, namely sequences of signs corresponding to 'morphemes'. These sign-groups have cross-links to the cursive ones, which were incised on various clay documents (inscribed clay 'cones', 'medallions', 'bars', pierced labels conventionally called 'lames') and on the clay sealings from the same complex (Olivier 1989a: 44). This attestation of the Hieroglyphic script on objects of two different materials forms the basis for reconstructing its use in an administrative framework.

Hieroglyphic seals were certainly being manufactured over a considerable length of time, and in different seal workshops (Poursat 1996: 103; Younger 1979: 266-267). At present, 155 examples are published (Hallager et al. 2011; Krzyszkowska 2012), dating from MM IB until MM IIB; their production seems to have ceased after the end of the Protopalatial period (Olivier and Godart 1996: 216-291; Hallager et al. 2011; Karnava 2000: 161; Krzyszkowska 2012). The development of different styles for rendering the script signs was certainly connected not only with the development of the carving techniques but also with the hardness of the materials used. For instance, by the end of MM IIB the Seal Cutter's Workshop at Malia specialised in the production of soft-stone prisms, which were engraved in the freehand technique (Anastasiadou 2011:60-61). Therefore, in this case the material and the technique impacted the appearance of both the seal motifs and the hieroglyphic signs, which were rendered in a simplistic manner. In general, though, the way the hieroglyphic signs were reproduced on seals strengthens the notion that during the MM II period the seal engravers were aware of what the form of the script signs would be, when incised on clay (Younger 1990: 88-92). The coherence in the syntax of the seal inscriptions and the knowledge of certain scribal conventions also reinforces the case for the adoption of writing by the artisans of the Seal Cutter's Workshop (Boulotis 2008: 78; Karnava 2000: 229-231).

But who were the intended readers of the inscriptions on the MM II hieroglyphic seals? Was the form of the seals sufficient to indicate their purpose or was the existence of the inscriptions on them purely symbolic? Neither of these questions can be answered with certainty; the frequent attestation of specific hieroglyphic sign-groups both on seal faces and on administrative clay incised documents suggests that hieroglyphic seals served as administrative instruments and were not used to carry incantations or magic spells (Olivier 1990: 19). We can hypothesise that they were commissioned pieces, presumably from individuals who could also read them (Karnava 2000: 231). A particular pattern in the use of the hieroglyphic seals emerges when we examine the Knossian 'Hieroglyphic Deposit', a discard assemblage of sealed documents, whose dating remains controversial (Olivier and Godart 1996: 28; Younger 1999: 381; also Schoep 2006: 46, n. 81 arguing for a MM IIIA dating). Sets of different hieroglyphic seals had been used in conjunction in stamping and counter-stamping the relevant sealed documents found in the deposit. In this case, not only the shape of the resulting documents but also the number of the seal inscriptions stamped on them with inscribed seals may have corresponded to an established administrative hierarchy of seal owners (Weingarten 1995). Among the various seal devices used to stamp in the Knossian Hieroglyphic deposit and also at Malia, those inscribed with the standardised two-sign formulae 'trowel' - 'arrow' (Olivier and Godart 1996: signs 044-049) and 'trowel' - 'eye' (Olivier and Godart 1996: signs 044-005) were possibly institutional Hieroglyphic seals (Jasink 2009: 11; Olivier 1990: 17-18; Weingarten 1995: 303, 307). Nevertheless, the script remains undeciphered and therefore, we cannot confirm whether the seal inscriptions referred to social status or to the seal owners' office, titles, responsibilities or even professions (Boulotis 2008: 75; Weingarten 1994: 179-180).

\section{An Alternative Interpretive Approach}

An alternative is offered by following a holistic approach and studying hieroglyphic seals mainly as symbolic devices. From the perspective of Peircean semiotics a 'symbol' is based upon a habitual and, therefore, arbitrary or conventional connection between 'sign' and 'object' (Peirce 1931: 


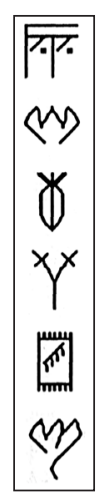

Figure 1: Examples of Cretan Hieroglyphic logograms (after Olivier and Godart 1996: 17).

369). With regard to symbols regulated by culture, this connection has to be perceived by a wider circle of people and not only by their owners. The semiotic significance of symbolic devices has to be renegotiated, each time they are transferred or inherited by the next generation. As a system of graphic notation "capable of transcribing linguistic statements" (Gelb 1952), writing also forms part of a symbolic behaviour, since textual signs call up their object by mediated habit (Robertson 2004: 18). The understanding of these signs presupposes the knowledge of the necessary code and, thus, necessitates initiation.

The hieroglyphic seal inscriptions share the same symbolic character with the standardised Hieroglyphic script, as attested on incised clay documents. Although most of the hieroglyphic signs are schematic depictions of human figures, animals or more or less recognisable objects, at a semantic level they do not identify with their visual form as pictographs do (Harris 1986: 32). In particular, some of the signs may have been logograms (Figure 1) representing a word or 'morpheme' and giving no indication of its phonetic value (Olivier and Godart 1996: 13, 17 table; Karnava 2000: 34). But most of the hieroglyphic signs probably functioned as syllabograms that corresponded phonetically to syllables. This applies also to the sign-groups that appear on the hieroglyphic seals, especially the ones that are attested on incised clay documents as well. Nonetheless, the linguistic function of the script signs on the hieroglyphic seals is blurred by the interspersed representational motifs that impinge upon the otherwise standardised inscriptions (Olivier and Godart 1996: 13-14, 17, 63). These motifs are sometimes decorative (e.g. spirals), but mainly pictorial in character (e.g. cat, wild boar, ibex, snake, U-sistrum, etc.). Depending on their size, they are either used as fillers of inscriptions (Figure 2a-b; also cf. CMS VI, 93, first sign on the left) or as solitary motifs on seal faces (e.g. Olivier and Godart 1996: \#256.a- $\beta$,

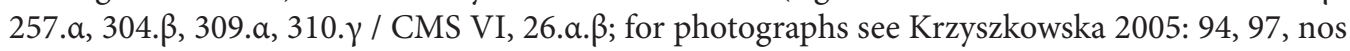
$161 \mathrm{a}-\mathrm{c})$. So far, there is hardly any consensus on whether these motifs had a 'decorative' function or were perceived as script signs, even though in some cases they also belong to the script signary (Karnava 2000; Krzyszkowska 2005: 95-98; Olivier 2000; Poursat 2000). Although several of the solitary seal motifs could allegedly also convey linguistic meaning as ideograms (Jasink 2009: 11, n. 53), at least when combined with each other (Anastasiadou 2011: 67, n. 365), the issue has to be further explored.

Let us now examine how the Minoan seals were gradually established as emblems, namely badges used to represent individuals or social groups, by examining their iconography and their material features. From a social perspective, the principles underlying the use of Prepalatial seals as sphragistic instruments for laying claims to resources are still an issue under discussion (Relaki 2009). These seals most probably functioned as means of personal and collective identification, as inferred from their final use, namely funerary deposition in communal graves which were used 


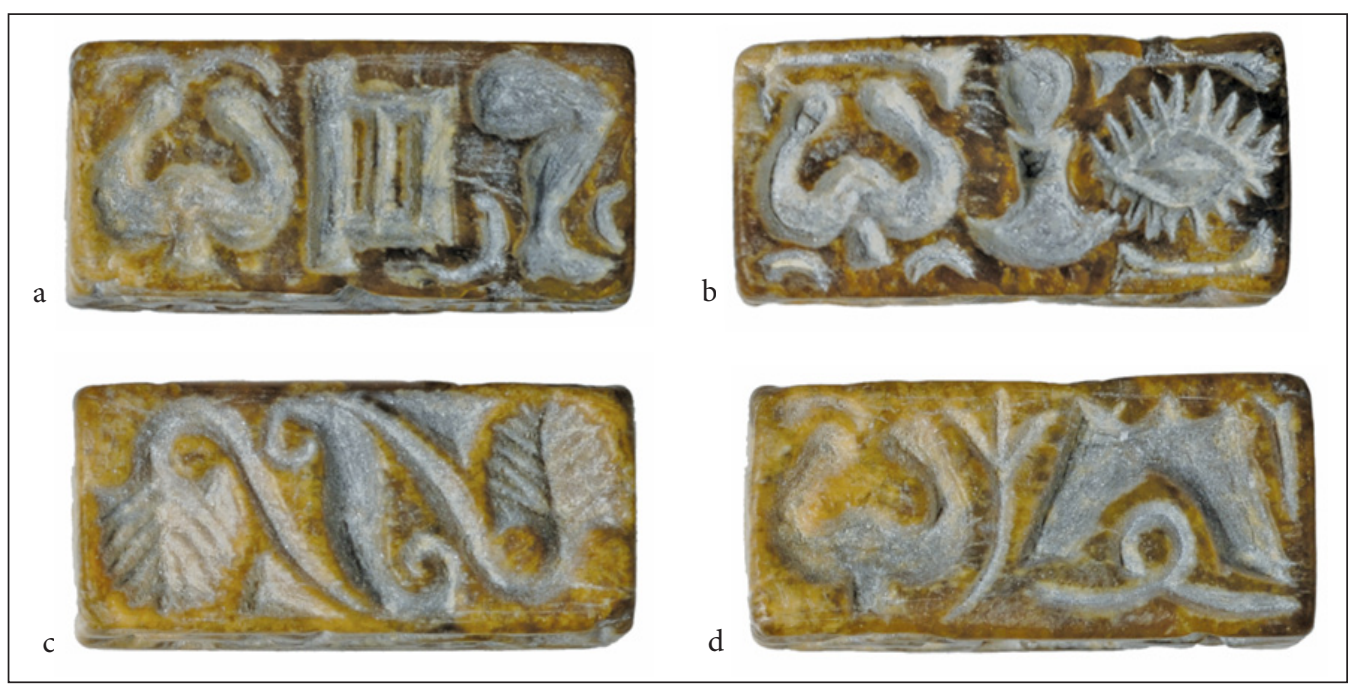

Figure 2: Four-sided steatite prism (Olivier and Godart 1996: \#288), HM S-K2184 from Malia with horizontally aligned signs. a) side $\alpha$; b) side $\beta$; c) side $\gamma$ with seal motifs; d) side $\delta$. Length: $1.54 \mathrm{~cm}$.

for many generations (Relaki 2009: 369; Sbonias 1999: 27). In a few cases where the devices were kept with their owners even in the process of secondary burial, for example at the cemetery of Phourni near Archanes (Karytinos 1998: 85), they must have represented their owners or users by mediated habit. In terms of their iconography, the evolution of seals from the Prepalatial to the early Protopalatial period (Sbonias 1995: 74-121; Yule 1980: 229-230) suggests a gradual rise in symbolic awareness. The use of abstract linear or geometric motifs on the Early Minoan II-III soft stone and bone seals (Figure 3a-c), such as intersecting lines, cross-hatching, hatched triangles, lattice, meanders, etc., gave way to the production of ornamental compositions and the first iconic representations as exemplified by the EM III-MM IA hippopotamus ivory seal groups (Figure 4a-e; cf. Krzyszkowska 2005: 60-68). The larger circular seal faces and the fine-grained material of the hippopotamus ivory bifacial cylinders and conoids encouraged innovative syntheses of schematic floral, animal or human motifs and geometric ornaments, which covered the whole field (Krzyszkowska 2005: 63, 66). The 'Parading Lions / Spiral Group' of seals (Figure 4b-d; Krzyszkowska 2005: 66, nos 111a, 111c) especially demonstrates how lions, scorpions, goats and spiders were arranged in a rotating syntax with no privileged direction. These pictorial syntheses recall the preliterate Mesopotamian seal motifs (Schmandt-Besserat 2007: 30-33), which likewise appear before the development of writing in their own area, and they testify to the adoption of a new symbolic Cretan repertoire during the late Prepalatial period. Moreover, the study of the burial assemblages from which they originate supports the hypothesis that they may have signified emergent social groups (Sbonias 1995; 1999).

\section{The First Definite Writing?}

The transition to the Protopalatial period (MM IA-MM IB) signals the beginnings of the direct association of script entities with images on seal devices, a phenomenon that was to continue with the later hieroglyphic seals. By contrast with the aforementioned pictorial syntheses and a group of steatite, bone and 'white paste' seals decorated with spirals, floral and animal motifs (Krzyszkowska 2005: 68-69), the earliest seals of the 'Archanes Script Group' bear engraved script 




Figure 3: Early Minoan II bone seals from the Ayia Triada tholos A with linear motifs. a) Height: $2.0 \mathrm{~cm}$. CMS II.1, no. 17 / HM S-K444; b) Height: 1.8 cm. CMS II.1, no. 18 / HM S-K445; c) Height: 1.8 cm. CMS II.1, no. 24 / HM S-K452.

signs in isolation or in sign-groups (Sbonias 1995: 108-111, 166, table 3). Seals CMS II.1, no. 394, CMS II.1, no. 393 and CMS II.1, no. 391 (Olivier and Godart 1996: \#202, \#252, and \#315, respectively) were recovered from secondary burial deposits in rooms I and II of Burial Building 6 at the Archanes / Phourni cemetery (Figure 5b-d). Although on the basis of associated pottery they have been dated to MM IA (Sakellarakis and Sapouna-Sakellaraki 1997: 326-330, 674, 680-681), their attribution to late MM IA-MM IB has been persuasively argued (Sbonias 1995: 108; Watrous 1994: 727, n. 241; Weingarten 2007: 137). Interestingly, the devices bear the earliest attested Minoan formulaic inscription, known as the 'Archanes formula. This consists of two standardised sign-groups (Olivier and Godart 1996: signs 042-019 and 019-095-052), which also occur later on other 'Archanes Script Group' seals, on the hieroglyphic seals, as well as on Neopalatial stone libation tables carrying the Linear A 'libation formula' (Godart 1999: 299-302). Although the 'Archanes formula' signs have been called 'pictographic' (Brice 1997: 94; Grumach and Sakellarakis 1966: 113), we should recall that pictographs are signs bearing a pictorial resemblance to their referent. The 'Archanes formula' signs are rather "a graphic depiction of certain objects, people, or events that have significance within a particular culture" (Nuessel 2006: 592) and, thus, are not considered as true writing. However, due to their occurrence in the two later writing systems it seems likely that the standardised sign-groups of the 'Archanes formula' semantically conveyed phonetic values and thus should be considered candidates for 'true writing' (Schoep 2010: 71).

Furthermore, the signs 'sistrum', 'leg', 'hand', 'double-sickle'; and 'ship', which during the MM II period form part of hieroglyphic sign-groups, emerged for the first time isolated on the following bone multi-faced seals of the 'Archanes Script Group' (Figure 6): CMS II.1, no. 287 from Platanos tholos B, CMS II.1, nos. 391 and 392 from Archanes and CMS II.1, no. 126 from tholos K at Kalathiana (Figure 7). Among these, the Archanes seal CMS II.1, no. 391 (Olivier and Godart 1996: \#315; Figure 8) demonstrates how its shape was chosen so as to provide the space for the display of signs with a probably different semantic function. A bone squared bar with a pierced cylindrical stalk is intersected at three points, thus, providing three cubes on which 14 seal faces with oval borders have been engraved. In a way which foreshadows the later hieroglyphic seals, 


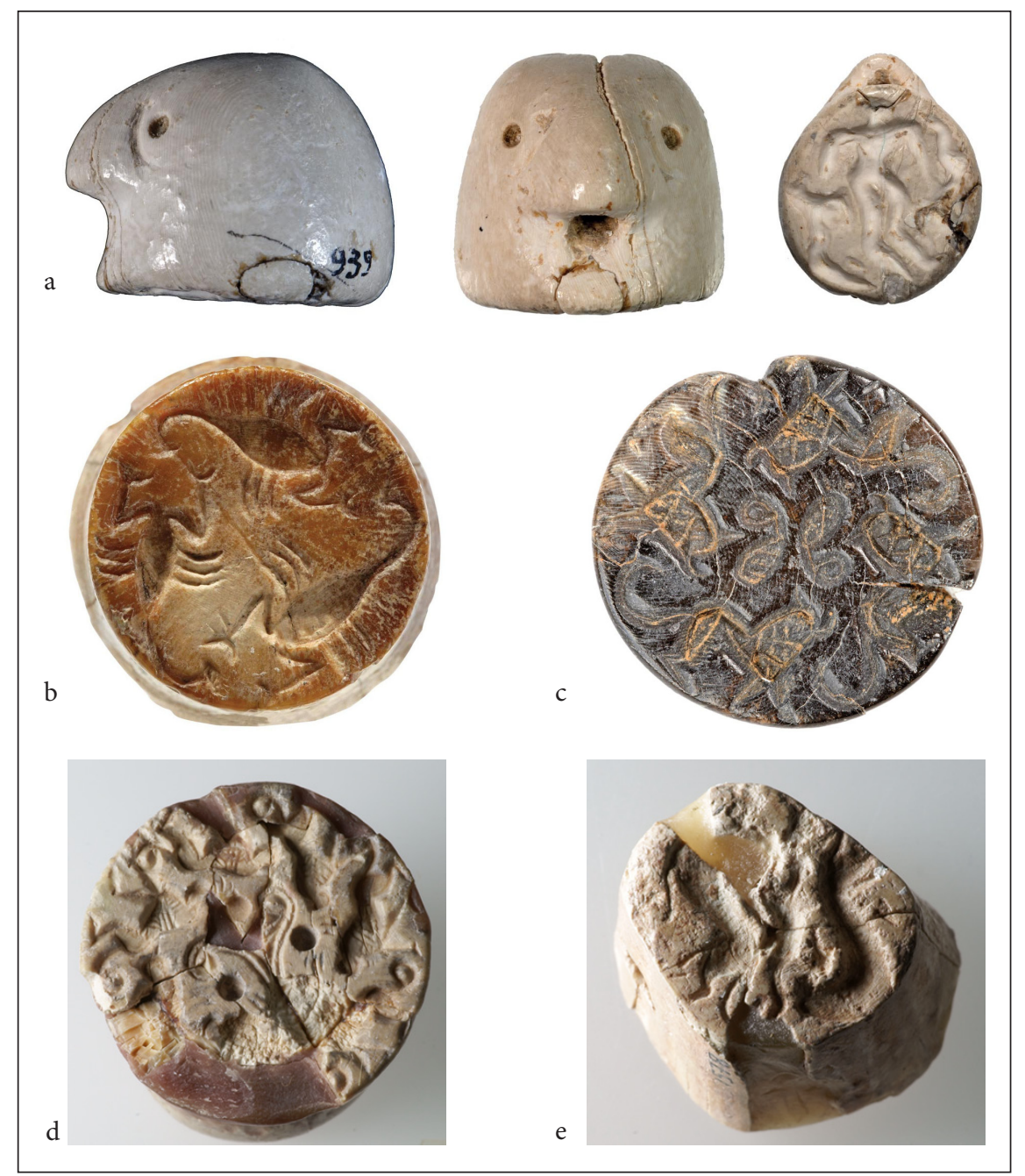

Figure 4: Early Minoan III-Middle Minoan IA hippopotamus ivory seals. a) Length: $2.3 \mathrm{~cm}$. CMS II.1, no. 469 / HM S-K939 from Sphoungaras; b) Length: $3.5 \mathrm{~cm}$; Width $3.5 \mathrm{~cm}$; Thickness 3.2 cm. CMS II.1, no. 248 / HM S-K1039 from Platanos tholos A; c) Length: $1.97 \mathrm{~cm}$; Width $1.9 \mathrm{~cm}$; Thickness $2.97 \mathrm{~cm}$. CMS II.1, no. 3 / HM S-K680 from Drakones tholos tomb D; d) Length: 3.33 cm; Width $3.32 \mathrm{~cm}$; Thickness $2.97 \mathrm{~cm}$. CMS II.1, no. 312a / HM S-K1104 from Platanos tholos B; e) Length $2.5 \mathrm{~cm}$ : Width $2.18 \mathrm{~cm}$. CMS II.1, no. 442b / HM S-K1578 from the Trapeza cave.

the solitary signs 'sistrum', 'leg', 'hand' and 'double-sickle' are juxtaposed with the usual seal motifs of the period (floral motifs, humans and animals accompanied by C- or S-spirals) as well as with the two 'Archanes formula' sign-groups. The latter and possibly another, now elusive, sign-group notably occupy the same side of the seal (cf. CMS II.1, no. 391, faces G-I; Olivier and Godart 1996: 291). Thus, by impressing just this side on clay, one would get a seal impression of the formula. This hierarchical arrangement of the signs indicates how this new multi-faced seal type may have been handled and used in a tactile sense, integrating legibility and embodied performance.

Another instance, where the two sign-groups of the 'Archanes formula' are combined with pictorial motifs on the other seal faces is shown by the bone cube S35 / HM S-K2850, which was deposited in a late Prepalatial ossuary of the Moni Odigitria cemetery (Olivier and Godart 1996: 




Figure 5: 'Pictographic' signs on the 'Archanes Script Group' seals and on later Hieroglyphic seals (after Sbonias 1995: table 3).

\#313; Sbonias 2010: 204-205, 219-219). Two of its seal faces bear a schematic quadruped along with space-filling ornaments and what may possibly depict a standing human figure accompanied by a hieroglyphic sign. This 'Archanes formula' seal from central-south Crete may allude to social interaction with north-central Crete and specifically the Archanes area, although it is hard to follow the suggestion that the seal reached the south through exchange (Sbonias 2010: 204-205, 219). In any case, the institutional importance of the early 'Archanes formula' seals can only be inferred by analogy to the sphragistic use of later seals with the same content, as will be outlined below. The final deposition of the early inscribed seals in bone ossuaries makes it impossible to deduce whether they had initially functioned as personal attributes or as emblems of a corporate group. Yet still, the occurrence of the formula on three seal devices from Burial Building 6 could point to the special rights of a particular social group or institution (Sbonias 1999: 46).

Whether the solitary pictorial signs on the aforementioned seals from Archanes (Figure 8) and Kalathiana (Figure 7) were equivalent of writing when read in sequence, as suggested 


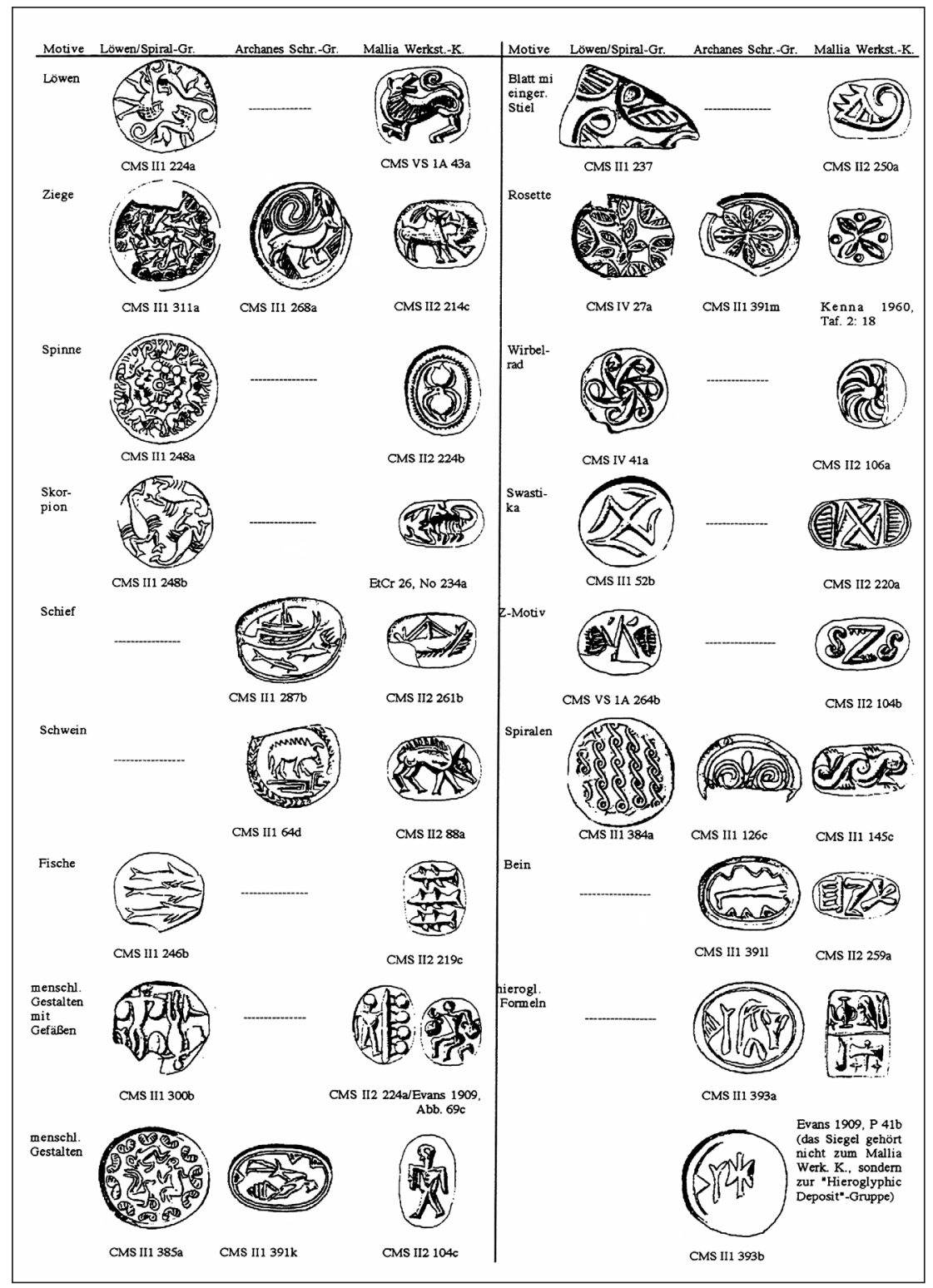

Figure 6: Seals that bear the 'Archanes formula' (after Brice 1997: 94, fig. 1).

(Sakellarakis and Sapouna-Sakellaraki 1997: 328, fig. 284; Sbonias 1995: 111), remains an open question. Arguably, they are not characterised by auto-indexicality (Coulmas 2003: 21), since they do not incorporate any information about the procedure of their own interpretation. Since they appear on symbolic devices which were used as markers of identity or status, it can be tentatively suggested that they were semasiographic codes without any phonetic value, but functioning as mnemonic aids; when impressed on early clay sealed documents, they would make a particular statement of ownership or responsibility. These codes probably stemmed from the emblematic use of Minoan seal devices at least since the late Prepalatial period. I would like to suggest that the combination of signs with a pictorial character and pure script signs on the Archanes Script Group' of seals possibly reflects a successful emulation of the imported Egyptian scarabs. The 




Figure 7: Seal, CMS II.1, no. 126 / HM S-K817 from Kalathiana tholos K. Length: 1.9 cm; Width $1.9 \mathrm{~cm}$; Thickness $1.9 \mathrm{~cm}$.

a



$\mathrm{b}$

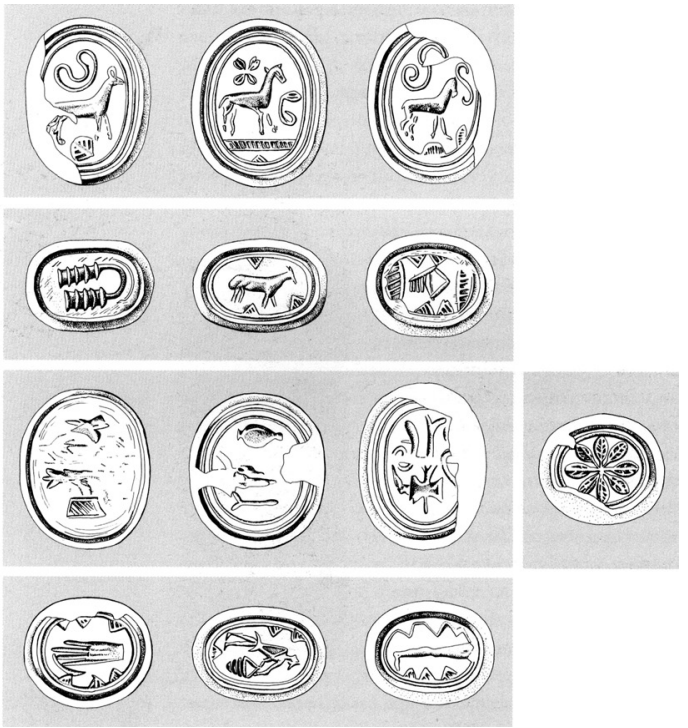

Figure 8: a-b) Archanes bone seal with the 'Archanes formula'. Length: $5.67 \mathrm{~cm}$; Height: $1.28 \mathrm{~cm}$. CMS II.1, no. 391 / HM S-K2260 (drawing after Sakellarakis and Sapouna-Sakellaraki 1997: fig. 284).

latter were deposited in MM IA Cretan tholos tombs and often incorporate C- or S-spirals and floral elements with Egyptian hieroglyphic signs (Aruz 2000: 2-3; Phillips 2010: 309, 313, fig. 3; see also Sparks, this volume). It may be relevant that the earliest imported scarab so far (CMS II.1, no. 395 / HM Y464), which probably dates to early MM IA, also comes from Burial Building 6, where the three 'Archanes formula' seals were found (Phillips 2008a: 123; Phillips 2008b: \#50, 33, 




Figure 9: a) 'Egyptianising' stone amulet from Knossos. Height: c.1.5 cm. HM S-K631; b) Zoomorphic seal of hippopotamus tusk from Platanos tholos tomb A. Length: $2.5 \mathrm{~cm}$; Width: $2.2 \mathrm{~cm}$; Thickness: $3.5 \mathrm{~cm}$. CMS II.1, no. 249 / HM S-K1040; c) Prepalatial bone amulet. Length: $3.0 \mathrm{~cm}$. HM O-E122; d) Prepalatial stone amulet. Length: $2.0 \mathrm{~cm}$. S-K1252.

302). An early interaction of Crete with Egypt is further supported by the 'Egyptianising' amulets and stamp seals (Figure 9a-b). The latter were first introduced into Crete in the EM III period and are carved with Egyptian imagery, such as the crouching baboon, a zoomorphic form of the god of writing (Thoth) and the lion (Aruz 2000: 3-4; Phillips 2008b: 227, 196; Phillips 2010: 314).

It is thus possible to suggest that the transformation of the early Minoan seal repertoire towards iconicity coincides with the gradual evolution of Minoan writing. Although the initial stages of the development of the 'Archanes formula' are elusive, it is tempting to see the appearance of the formula on seals with an emblematic function as meaningful. So, it may be possible that the formula's constituent signs evolved out of a gradual transformation from a representational to a symbolic function, as exemplified by the 'Parading Lions / Spiral Group' and 'Archanes Script Group' seals. The contention that emblematic devices, such as seals, may have been one of the sources of inspiration for symbolic visual imagery is reinforced by cross-cultural analogies relating to the earliest stages of other Near Eastern scripts. ${ }^{6}$ Early iconic emblems drawn from the natural and ideal world and charged with a symbolic content are seen as connected with script invention in Predynastic Egypt, as shown by the finds from tomb $\mathrm{j}$ in cemetery $U$ at Abydos (Baines 2004: 157161, 164; Dreyer et al. 1998; Kahl 1994: 53-56, fig. 3; see also Piquette, this volume). A stronger analogy can be found between the 'Archanes formula' and the development of proto-cuneiform in Mesopotamia during the $4^{\text {th }}$ millennium, a script which emerged from a long tradition of pictorial and symbolic representation found, in particular, in glyptic art (Cooper 2004: 77). In a similar 
vein, it has been recently suggested (Dahl 2009) that the marks of Proto-Elamite writing also support the relationship of this early script with seals.

On the other hand, the close connection of the Hieroglyphic script with material objects is supported by the fact that some of the MM II Hieroglyphic signs may recall earlier three-dimensional artefacts, such as amulets and specific types of seals. Minoan zoomorphic and anthropomorphic stamp seals were produced for the first time in the Prepalatial period. As suggested by a persistent conservatism in their shape (Sbonias 1995: 44-45), these seals probably had the same function as contemporary bone and stone amulets (Figure 9c-d) in the shape of whole animals, animal feet and everyday objects (Branigan 1970: 94-97, fig. 22). The shapes of two other Hieroglyphic signs are possibly derived from three-dimensional objects which had a symbolic meaning, namely the double axe and the Egyptian sistrum. ${ }^{7}$ Both were initially employed on the 'Archanes Script Group' seals. Nevertheless, any possible link between these objects and the initial meaning of the relevant hieroglyphic signs at the stage of the invention of the latter is likely to have waned by the MM II period.

In the Protopalatial period, the two sign-groups of the 'Archanes formula' could be engraved either separately on different seal faces or together (Figure 5: examples $\mathbf{a}, \mathbf{e}-\mathbf{h}$ ). This arrangement is also attested by the relevant seal impressions on clay sealed documents. For example, only the first sign-group of the formula 'axe' and 'fish' (Olivier and Godart 1996: signs 042-019) occurs on the clay documents CMS II.8, no. 56 (Olivier and Godart 1996: \#134 and \#135-137). Thus, using one or both parts of the 'Archanes formula' required pre-planning by the seal engraver, since it depended not only on choosing the appropriate seal shape, but sometimes also on the decision to place the two sign-groups on the same seal face or not. For instance, one of the two faces of the stamp seal CMS VII, no. 35 (Olivier and Godart 1996: \#205; Figure 10a) shows both parts of the formula arranged together in two panels, while the other face depicts an ibex (Kenna 1967: 64). The arrangement of the full formula on a single prism face made it much easier to produce seal impressions on small clay documents, as shown by the partly preserved Knossian sealing CMS II.8, no. 40 (Olivier and Godart 1996: \#179; Figure 10b). However, the three-sided steatite gable-shaped seal CMS VI, no. 14 shows that the formula could also be combined with a third sign-group. Interestingly, only the side with the second sign-group of the formula bears traces of intensive use (Olivier and Godart 1996: 253, \#251). The same seems to hold true for the earlier bone 'Archanes formula' seal CMS II.1, no. 394, but not for CMS II.1, no. 393 (cf. Sakellarakis and Sapouna-Sakellaraki 1997: fig. 291).

\section{Alignment and Directionality}

The question of how MM II Hieroglyphic writing was perceived by the readers mainly relates to the parameters of alignment and directionality. Alignment refers to the relative position of the graphs with respect to each other, whereas directionality concerns the direction in which they were read. In the standardised incised Hieroglyphic documents, the signs are generally aligned horizontally and directed from right to left (CHIC: 62-63). The scribes usually prefixed an initial cross' or ' $\mathrm{x}$ ' to the beginning of words and phrases, to let the reader know the direction in which these were to be read. The occasional absence of this 'initial cross' implies that the active script users were usually well trained and acquainted with the script (Karnava 2000: 230). By the late Protopalatial period, the same patterns of alignment were reinforced for the signs engraved on seals with the introduction of the 'frieze syntax' (Yule 1980: 65-68). The new popular shape of elongated prisms with three or four faces (Figure 2a-d) allowed the carving of motifs and signs in a clear horizontal alignment, so that the inscriptions were more easily read when impressed on clay. An added benefit was that this alignment corresponded to the organisation of the incised clay documents with the exception of the 'medallions', which due to their shape encouraged a circular arrangement of the inscriptions (MNAMON 2009-2012). More significantly, the material of the 




Figure 10: a) Agate stamp seal. CMS VII, no. 35 (Olivier and Godart 1996: \#205); b) Knossian sealing. Length: $1.4 \mathrm{~cm}$; Width 0.7 cm. CMS II.8, no. 29 / HM S-T372.

prisms, soft or hard stone, probably reflected different bureaucratic levels of responsibility, as stone type seems interrelated with the number of inscriptions. Soft stone prisms usually bore one face with an inscription, whereas the hard stone prisms - whether three- or four-sided - had most or all of their seal faces inscribed (Anastasiadou 2011: 66-67; Poursat 2000: 187-191). The fact that hard stones produced sharper clay impressions may explain this choice. At an iconographic level, the seal motifs used on prisms generally comprise human figures, goats, bucrania, schematically rendered quadrupeds, vases, ships, etc. An emphasis on depictions of human activities such as pot making, grape stamping, fishing and archery can be discerned. One possible interpretation of this development is the formation of new corporate groups within late Protopalatial society, which aimed to project their group identity in this manner.

Other Protopalatial seal devices of an elongated shape (e.g. amygdaloid or hemicylinder ones and seals with foliate backs) also produced a horizontal alignment (Karnava 2000: 165-173, table 32). An alternative to the horizontal layout of the inscription, such as division into four panels with groups of signs, is exemplified by the flattened cylinder CMS III.1, no. 149 (Olivier and Godart 1996: \#206; Figure 11a-b). This variability in composition may indicate that seal engravers enjoyed a certain degree of freedom in how they chose to organise the seal imagery. Interestingly, the veined material of the cylinder reduces the legibility of the inscription, while readability from its clay impression would have been easier.

At this juncture, let us consider how the lack of alignment and directionality that characterises some Protopalatial Hieroglyphic seals with round or ellipsoidal faces (Figure 12a-b) can be explained. These shapes may have denoted a different sphere or level of administrative responsibility, although this cannot be demonstrated with certainty (Karnava 2000: 166-167). But even the signs that seem to move on these seal surfaces were probably meant to be read, as suggested by the 'initial cross' that appears on many of them (Figure 13). It can be posited that these signs employed two-dimensional space in an alternative way, like graphics often do (Hill-Boone 2004: 317-318). We can also draw a comparison with the lack of a horizontal alignment in many Greek 


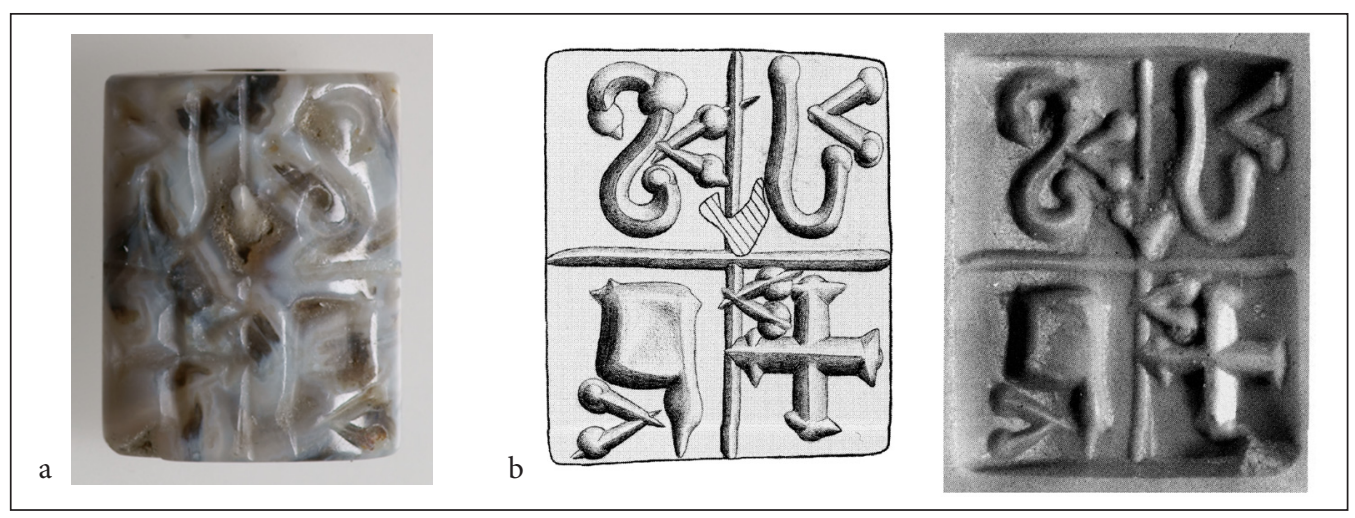

Figure 11: a) Flattened cylinder of agate, CMS III.1, no. 149 (Olivier and Godart 1996: \#206); b) Drawing and cast.

inscriptions of the Archaic period. For example, all available flat surfaces of a bronze aryballos from Menelaion were exploited by an incised boustrophedon inscription, whose alternate lines run in opposite directions (Catling and Cavanagh 1976: 145-153, figs 1-2).

With regard to the content of the inscribed prisms, it has been argued that the number of the inscribed faces was related to the status of their owners and to the sign-groups they were allowed to use administratively (Poursat 2000: 189). In this case, the shape of the prism could have functioned as a signifier of the administrative authority of the social agents, as it provided the surface for engraving meaningful recurring sign-groups and their combinations (formulas). By examining the Hieroglyphic seals material, Karnava (2000: 200-201) has established that a standardised formula normally contained one to three of the common sign-groups, and one uncommon, probably intended to make each seal unique, perhaps personalising it. Nevertheless, the two most frequent sign-groups 044-049 and 044-005, which possibly stood for administrative entities, as discussed above, could have an autonomous meaning, since the first is more often associated with three-sided prisms bearing just one inscribed seal face (Karnava 2000: 200 ; Olivier 1990: 17).

However, it is difficult to assess how sign alignment and directionality influenced the understanding of the engraved inscriptions on the three- or four-sided prisms and of their negative impressions on clay. The alignment of the individual signs is characterised by a marked fluidity, making it difficult to define their 'standard' position (Olivier 1990: 15, n. 16). Additionally, there is no consistent orientation in which the sign-groups are engraved on the various faces of the same seal. Younger (1990: 88-92) has tentatively supported the hypothesis that the meaning of the inscriptions may rely on two or three impressed faces being read together. For this reason, the literate seal engravers possibly oriented the inscribed faces, either to form complementary meanings, or to facilitate separate impressions and readings. For example, on CMS XII, no. 112 (Olivier and Godart 1996: \#287) the side with a horizontal layout is the one bearing the main hieroglyphic inscription. The other two inscriptions (044-049, 044-005) were arranged at right angles to the horizontal one, so that the seal user had to turn the seal $90^{\circ}$ degrees in order to impress them on a clay sealing. However, this layout does not seem to support the view (Karnava 2000: 231) that the persons who used the seals as an impressing medium were illiterate.

Moreover, the seal engravers seem to have deliberately organised the figurally decorated and the inscribed seal faces to contrast with each other (Younger 1990: 92). As discussed above, the question of whether the 'decorative motifs' engraved on separate seal faces were really meant to be understood as script signs or as simple pictorial motifs, has not been satisfactorily answered yet. It has been suggested that this could be considered as a case of indirect representation, whereby the 
a



$\mathrm{b}$

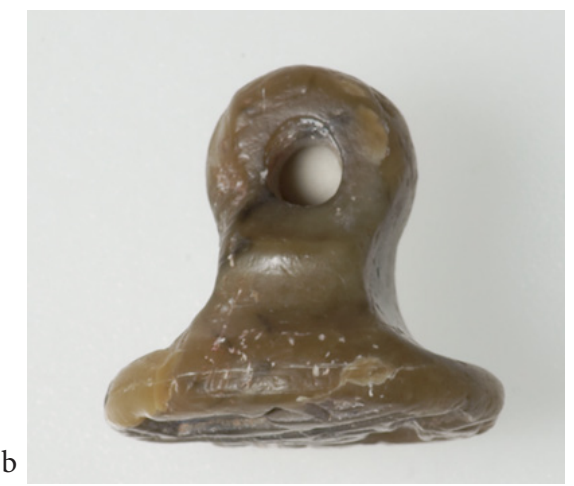

Figure 12: Steatite petschaft seal, CMS III.1, no. 103 (Olivier and Godart 1996: \#180). a) Seal face; b) Profile.

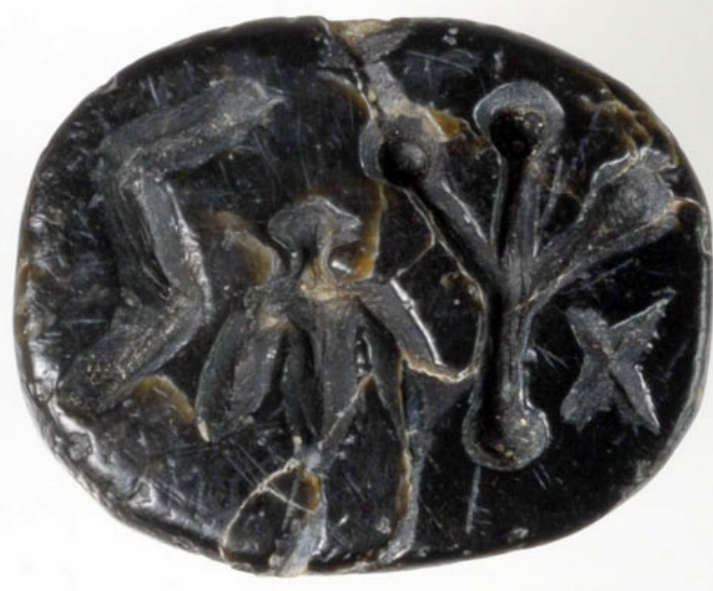

Figure 13: Quartier Mu steatite signet (Olivier and Godart 1996: \#197). Length: $1.35 \mathrm{~cm}$; Width $0.8 \mathrm{~cm}$. HM S-K2390.

signs had not yet been transformed from 'icons' to symbols with phonetic value (Knappett 2008: 149-150). However, the different levels of arrangement of the so-called 'decorative motifs' and of their relationship with the script signs do not follow a linear chronological development (Karnava 2000: 174-189). So, when the script signs are transformed through the incorporation of decorative elements or, when they seem overtaken by the size of space-filling motifs, such as full-length human or animal figures or bucrania, they most possibly reveal the seal engraver's choice. Overall, however, due to the lack of conclusive contextual evidence which permits dating, it is difficult to detect any iconographic code that may have distinguished similar Hieroglyphic seals from each other and, by extension, their owners, as has been suggested (Weingarten 1995: 307). 


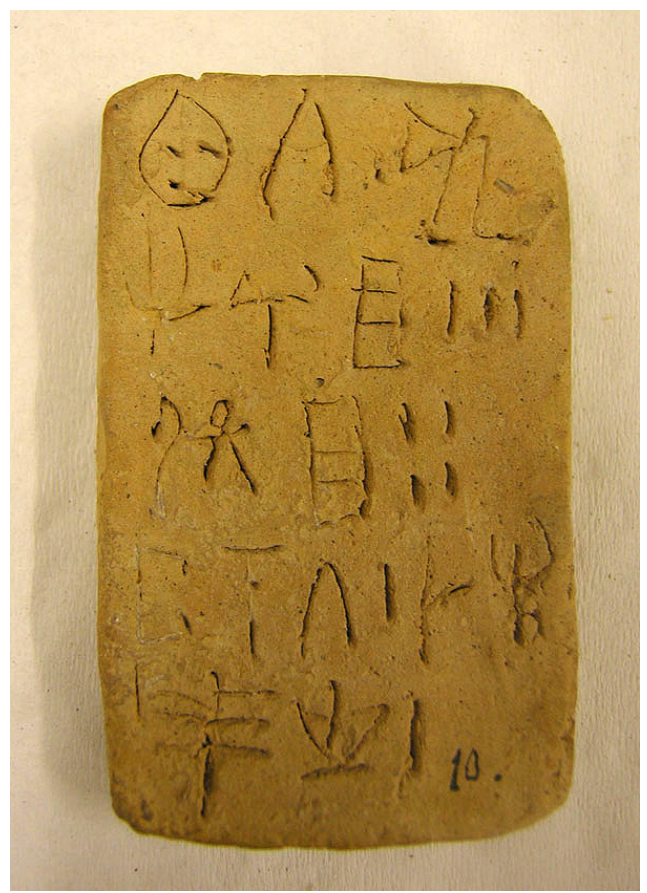

Figure 14: Linear A clay tablet. Height: $1.8 \mathrm{~cm}$. HT 7 / HM P-N10.

\section{Linear A: The social and cultural construction of Neopalatial literacy}

\section{Administrative Uses}

By the end of the MM III period, Linear A was the script used in most of the Cretan sites. The presence of many private Linear A clay archives and the circulation of inscribed documents outside Crete during the LM I period (Bennet 2008: 12) point to a widely distributed literacy, at least with regard to the ability to read. Persons actively involved in economic activities and merchants or traders would arguably have been literate or at least able to use logograms and numerical signs for basic notation (Boulotis 2008: 78). This hypothesis is corroborated by the fact that the standardised rules governing Linear A inscriptions on clay documents are practiced across different regions of the Aegean. The signs are always aligned horizontally and follow a left to right directionality (dextroverse inscriptions; Figure 14). But these rules, attested on clay objects, are not followed strictly on other materials, as discussed below.

\section{Non-Administrative Uses}

Linear A was also employed for purposes other than administration. Apart from some occasional painted inscriptions on pottery, carved or incised examples are found on a variety of durable material supports. These comprise architectural stone blocks, wall plaster, pottery, stone ritual and votive vessels, metal vessels, jewellery and a steatite seal from Knossos (CMS II.3, no. 23 / HM SK843). None of the inscriptions on these materials qualify as political statements (Schoep 2002b: 30), not even the two examples originally carved onto stone blocks, which were subsequently incorporated in a wall at the palace of Malia (Pelon 1980: 224, no. 301) and in the Kephala tholos grave near Knossos (Ze 16; cf. Godart and Olivier 1982: 138; Hood 1997: 116, pl. 1). Although 

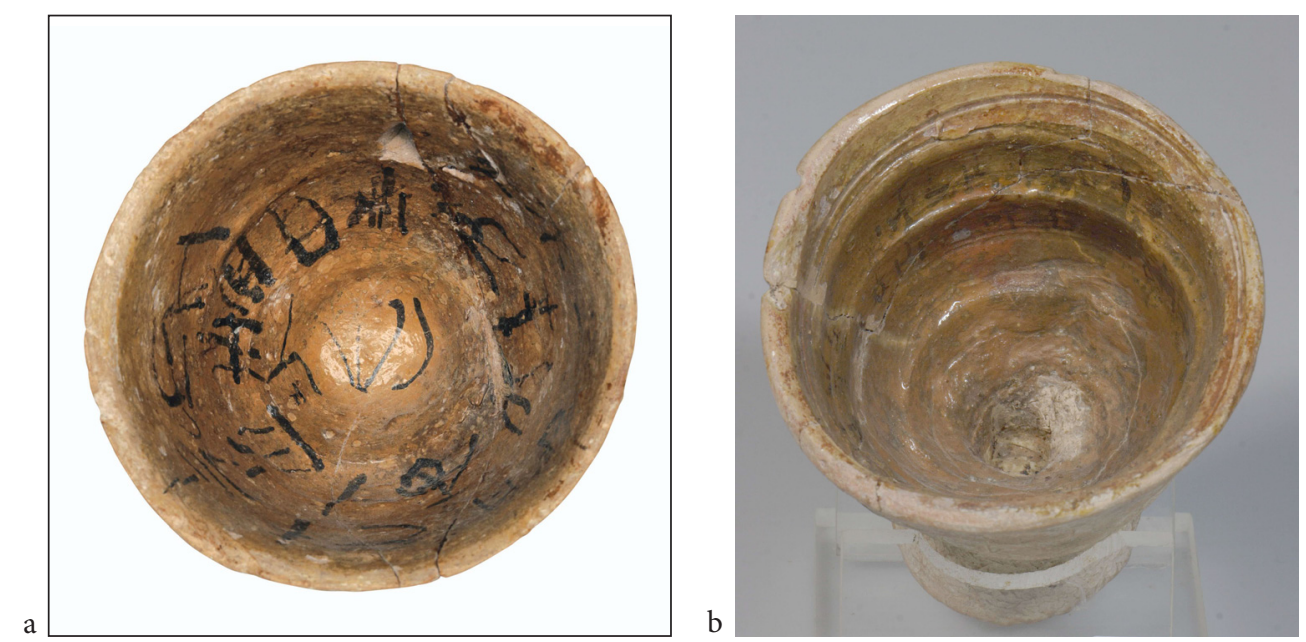

Figures 15: a) Ceramic conical cup. Diameter of rim: 8.4 cm. KN Zc 6 / HM P2630; b) Ceramic conical cup. Diameter of rim: $9.2 \mathrm{~cm}$. KN Zc 7 / HM P2629.

the script remains undeciphered, it would not be unreasonable to assume that these architectural inscriptions were used to perpetuate the historical memory.

The compositional interaction of writing with image that had been characteristic of the Cretan Hieroglyphic script seems to have diminished in the Neopalatial period. Narrative scenes set in architectural contexts were never combined with writing (Cameron 1968: 59 presents a doubtful example). Moreover, no decorative pictorial elements were ever integrated into Linear A inscriptions. Following the evolutionary scheme of Arthur Evans (Evans 1909: 8-18, 134-148), researchers tried to explain the linear morphology of the signs themselves by suggesting that Linear A was a simplified script that evolved from the Hieroglyphic, but this argument is open to dispute (Bennet 2008: 5). Signs carved with chisels or even finer-tipped implements on steatite and serpentine objects and on small metal artefacts are distinguished by a more elaborate, 'archaic' character. A possible explanation for this may be the notion that their writers followed an 'inscriptional tradition' with close familiarity with the scripts (Schoep 2002a). But how was Linear A writing on artefacts that were produced outside the administrative sphere perceived? With regard to inscriptions rendered in materials other than clay, the type and size of the inscribed artefacts as well as the arrangement of the inscription thereon have to be considered in relation to the specific features of the artefactual context (Knappett 2004: 46). Differences in signs resulting from the inscribing techniques employed, as well as restrictions imposed by the materials used or by the shape of the inscription-carriers, are also considered below.

\section{Alignment and Directionality}

Linear A inscriptions on non-administrative objects are accentuated by variable alignment and directionality. The performative capacities of the materials and the shape of the artefacts seem to have been factors which influenced the use of the graphic space. The two clay handleless cups KN Zc 6-7 from a house basement at Knossos (Figure 15a-b) and the inscribed gold ring KN Zf 13 from Mavrospelio cemetery (Figure 16a) serve as examples whereby the available surface may have dictated a spiral arrangement (cf. Godart and Olivier 1982: 118-125 and 152-153, respectively). This arrangement makes sense in the context of the small circular bezel of the gold ring (diameter $1.0 \mathrm{~cm} \times 0.85 \mathrm{~cm}$ ). In comparison, placing the ink inscriptions on the interiors of the 

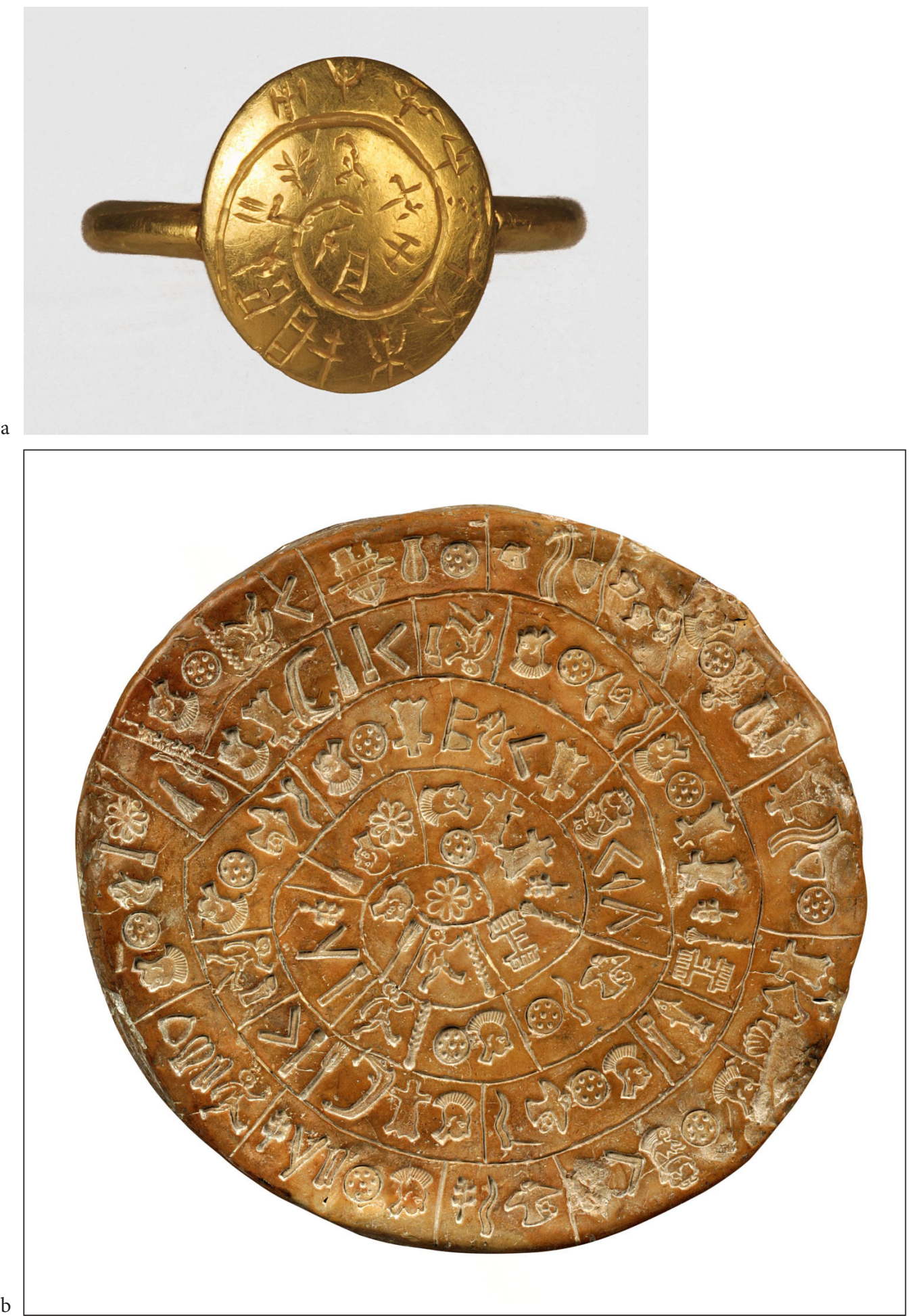

Figure 16: a) Mavrospelio ring made of gold. Diameter: $1.0 \mathrm{~cm} \times 0.85 \mathrm{~cm}$. KN Zf 13 / HM X-A530; b) Phaistos disc with stamped inscription, made of clay. Diameter: $15.8 \times 16.5 \mathrm{~cm}$. 


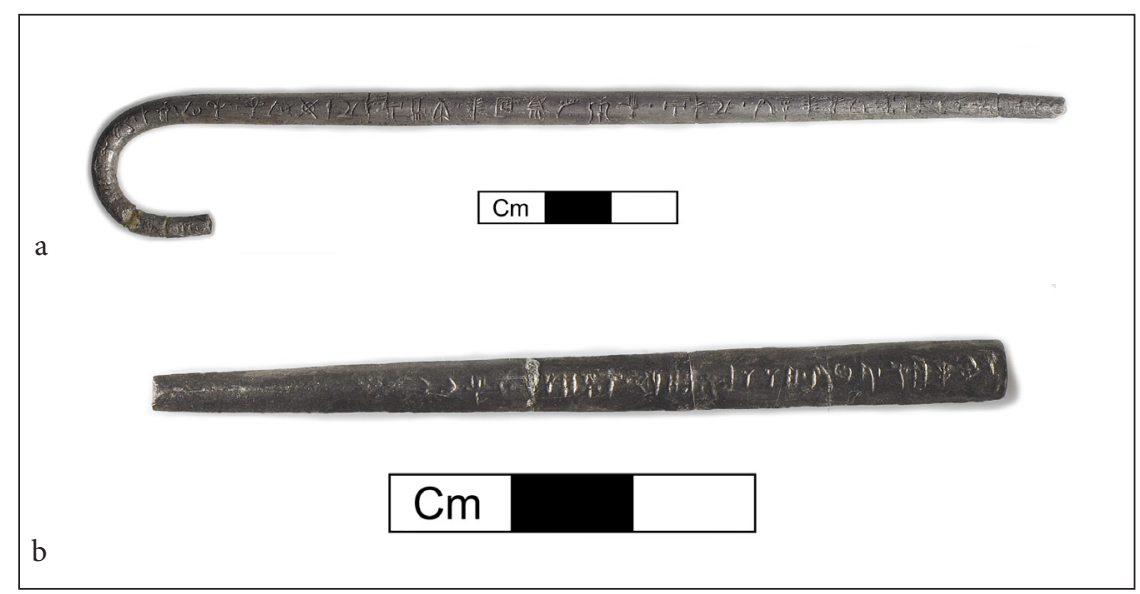

Figure 17: a) Silver pin. Length: $15 \mathrm{~cm}$. KN Z 31 / HM X-A540; b) Silver pin. Length: $7 \mathrm{~cm}$. PL Zf 1 / HM X-A498.

aforementioned cups, rather than the exteriors, may have related to visibility during their use as drinking vessels. As with archaic and classical kantharoi, holding the cups in order to fill them or to drink from them would have displayed the inscriptions. The readability of the inscriptions by the holder of the cup was facilitated by painting the cursive signs with their top towards the bottom of the cups, and also by directing the dextroverse spiral inscriptions from the centre of the base towards the rim. That the two painted inscriptions were meant to be read is also supported by visual reinforcement of the intended reading sequence: the beginning and the end of the second sign-group of cup KN Zc 6 (Figure 15a) were divided by a punctuation mark. The suggestion that the cups formed part of a foundation deposit for a new architectural phase of the building (end of the MM IIIB or early LM IA), because they bore magical spells and incantations (Banou 2001: 196), cannot be confirmed. Judging from the non-formulaic and non-consecrational nature of the inscriptions (Raison 1963: 25; Raison and Pope 1981: 223-224), the alternative hypothesis that they bore a dedicatory inscription seems more plausible (Evans 1921: 613-616).

By contrast, the inscription on the Mavrospelio ring KN Zf 13 can be compared to the stamped inscription on the Phaistos disc (Figure 16b). It is aligned along a spiral line and reads from the outer edge to the centre of the bezel. In contrast to the cups, however, the top of the signs face outwards. The comparison with the disc, which may convey a religious hymn (Boulotis 2008: 76; see also Whittaker, this volume), and the absence of separation marks between the sign-groups reinforce the probable magical underpinnings of the ring inscription. The final use of the ring as a burial gift deposited in the rich Mavrospelio tomb IX further supports the notion that it may bear a spell related to the ring's owner (Boulotis 2008: 75). Although it is unclear whether the ring was initially associated with the larnax found in the niche of chamber E1, its presence and the rest of the content of the chamber point to the high status of the burials (Forsdyke 1927: 266-267, 269). The inscribed silver pin KN Z 31 (Alexiou and Brice 1972: 113, n. 2, 116), which was recovered from another chamber of the same tomb offers further evidence in this respect (Figure 17a). A possible interpretation is that it may have been commissioned by another member of the same family or kin, who either had special ties with writing or was eager to legitimise his / her role through owning such a pin.

Inscriptions on this pin and also on three other LM I examples of precious metal associated with high-status burials at various sites have been interpreted as statements of a magical or religious character (Boulotis 2008: 75; Figure 17b; PL Zf 1; cf. Alexiou and Brice 1976: 18; ARKH Zf 9; 
a

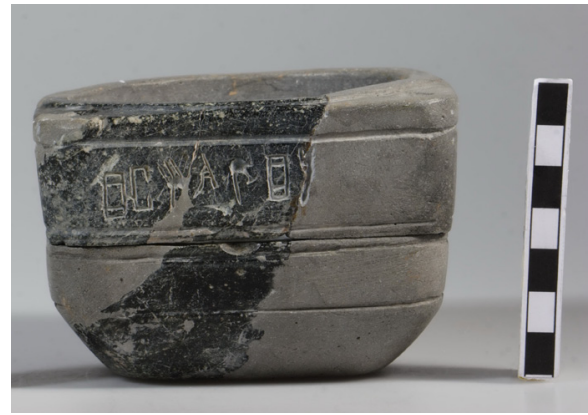

b

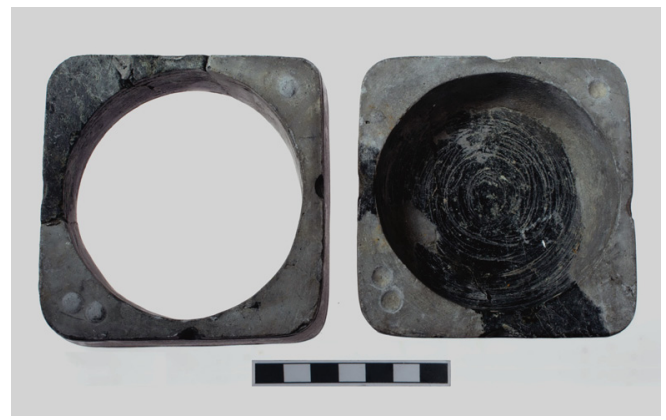

Figure 18: a) Stone libation table from Apodoulou with its two parts joined. Height: $6.5 \mathrm{~cm}$. AP $\mathrm{Za} 1$ / HM L2478; b) The two parts of the libation table separated.

cf. Sakellarakis and Sapouna-Sakellaraki 1997: 333, fig. 296; CR(?) Zf 1 / Ayios Nik.Mus. 9673; cf. Godart and Olivier 1982: 162). From a material point of view, the inscriptions were engraved after the silver or gold was cast and the material used affected the form of the signs to some extent. For example, the engraving of the signs using numerous small strokes onto the soft material of the gold pin $\mathrm{CR}($ ?) $\mathrm{Zf} 1$ from eastern Crete accounts for their angular shape, as is also the case with the aforementioned gold ring KN Zf 13 (Schoep 2002a: 14). From an epigraphic perspective, the inscriptions on the pins are mostly hapaxes (one-offs) separated into numerous sign-groups by punctuation strokes (Olivier et al. 1981: 12, 14). Since these differ considerably from a palaeographic point of view and come from remote findspots, the pins could conceivably have been produced by different workshops (Schoep 2002a: 14).

In terms of the use of graphic space, the elongated shape of the hairpins dictated the horizontal alignment of the inscriptions. Nevertheless, this did not preclude a different orientation for individual signs, as attested on the silver pin KN Zf 31 from Mavrospelio (Figure 17a). The sign A310 that stands exactly at the end of the hook has been turned $90^{\circ}$ clockwise (Godart and Olivier 1976: 313, pl. 2). With regard to directionality, only the inscription on the pin PL Zf 1 from Platanos (Figure 17b) reads from right to left (Alexiou and Brice 1976: 20-25). Overall, the material qualities of these hairpins were successfully manipulated for the addition of inscriptions. Due to their very small scale these inscriptions had to be held close to the eyes in order to be read. Although this quality does not seem to lend itself to a use of these objects for conspicuous display, writing must, in any case, have lent special symbolic properties to them. The final deposition of the pins as part of the burial assemblages indicates that they were personal items with emblematic value.

Two inscribed miniature double axes, one of gold and one of silver (AR Zf 1-2; cf. Godart and Olivier 1982: 162), which were deposited at the end of MM III in the Archalochori cave as part of a homogeneous hoard of metal objects, present a different social context from the burials (Marinatos 1962; Michailidou 2003: 302-303, 308-309). Although these two examples bear the same inscription, they differ palaeographically. The possibility that they came from the workshop, which produced the large bronze double axe with the unique inscription and the other large or miniaturised examples of the Arkalochori hoard (Boulotis 2008: 69, fig. 2), reinforces the contention that artisans working in metallurgy possessed some degree of literacy (Boulotis 2008: 78; Olivier et al. 1981: 22). The fact that metal objects of a functional character were also occasionally inscribed may also support this argument; examples include a lead weight from Mochlos (MO Zf 1; cf. Olivier 1989b) and a bronze axe at the British Museum (KA Zf 1 / BM 1954 10-20 1; Godart and Olivier 1982: 149).

Material aspects can be more explicitly studied as a symbolic index in the case of Neopalatial stone votive offerings with inscribed incantations reflecting the use of a common religious language 


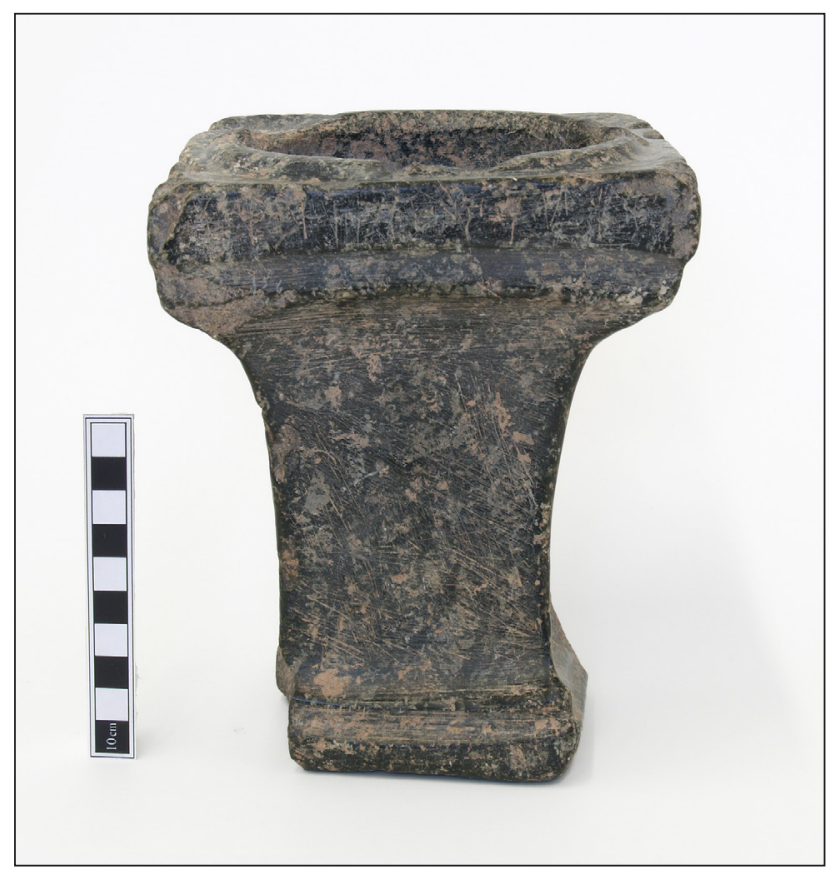

Figure 19: Stone libation table from Palaikastro. Height: $18.3 \mathrm{~cm}$. PK Za 11 / HM L1341.

throughout large parts of Crete (Driessen 1994: 114). Although evidence for their production is scarce, the elaboration of the signs and their palaeography differ from site to site suggesting different places of manufacture (Schoep 2002a: 14). Inscribed stone 'libation tables' were mainly deposited at peak sanctuaries along with uninscribed examples. One of their uses is evidenced by their inclusion in deposits of carbonised remains mixed with pottery, animal bones and votive objects, such as the ones excavated at the extra-urban sanctuaries. The earliest securely-dated inscribed example comes from Building Ub in the Kato Syme sanctuary, where libation tables and MM IIIA cups were deposited around the remains of a series of fires (SY Za 6; cf. Muhly in Muhly and Olivier 2008: 198). On the whole, the data suggests that inscribed libation tables were intended for offerings; they were possibly used in performance rites that formed part of a popular cult involving food and drink consumption. Most seem to have followed a votive etiquette, as shown by the recurring variations of sequential sign-groups, including the standard Linear A 'libation formula' (Duhoux 2001: 182; Younger 2002). The exact meaning of the sign-groups is presently unknown, but they may have formed parts of prayers or expressions of thanks to the deities. The proposed phonetic transcription of the 'libation formula' [j]a-sa-sa-ra-me, has been interpreted as either being addressed to a presumed goddess (Grumach 1968: 15-17) or meaning 'sacred boon or homage' (Facchetti 1999: 130).

A few vessels inscribed with variations of the formula also occur in domestic contexts, such as Knossos, Prassas and Apodoulou (Schoep 2002a: 14). Among the numerous libation tables that were offered at sanctuaries, the inscribed examples represent a very small percentage of the total (Karetsou 1987: 86). At the sanctuary of Kato Syme, where at least 600 libation tables have been recovered, inscribed examples form less than $0.02 \%$ (Muhly in Muhly and Olivier 2008: 199-200). Their low incidence implies that the inscribed libation tables may have been offered by members of privileged or distinctive social groups (Schoep 1994: 20). Among the uninscribed examples of different shapes found at Syme, the most obvious distinguishing factor was size. In a halfdozen cases, which were probably set up on tall bases, the total height could be significantly larger, 



Figure 20: a) Stone libation table. Height: $1.9 \mathrm{~cm}$ : Width $4.3 \mathrm{~cm}$. IO Za 2 / HM L3557 from Ioukhtas; b) Stone cup. Diameter $4.2 \mathrm{~cm}$ : Height: $2.5 \mathrm{~cm}$. IO Za 6 / HM L3785 from Ioukhtas.
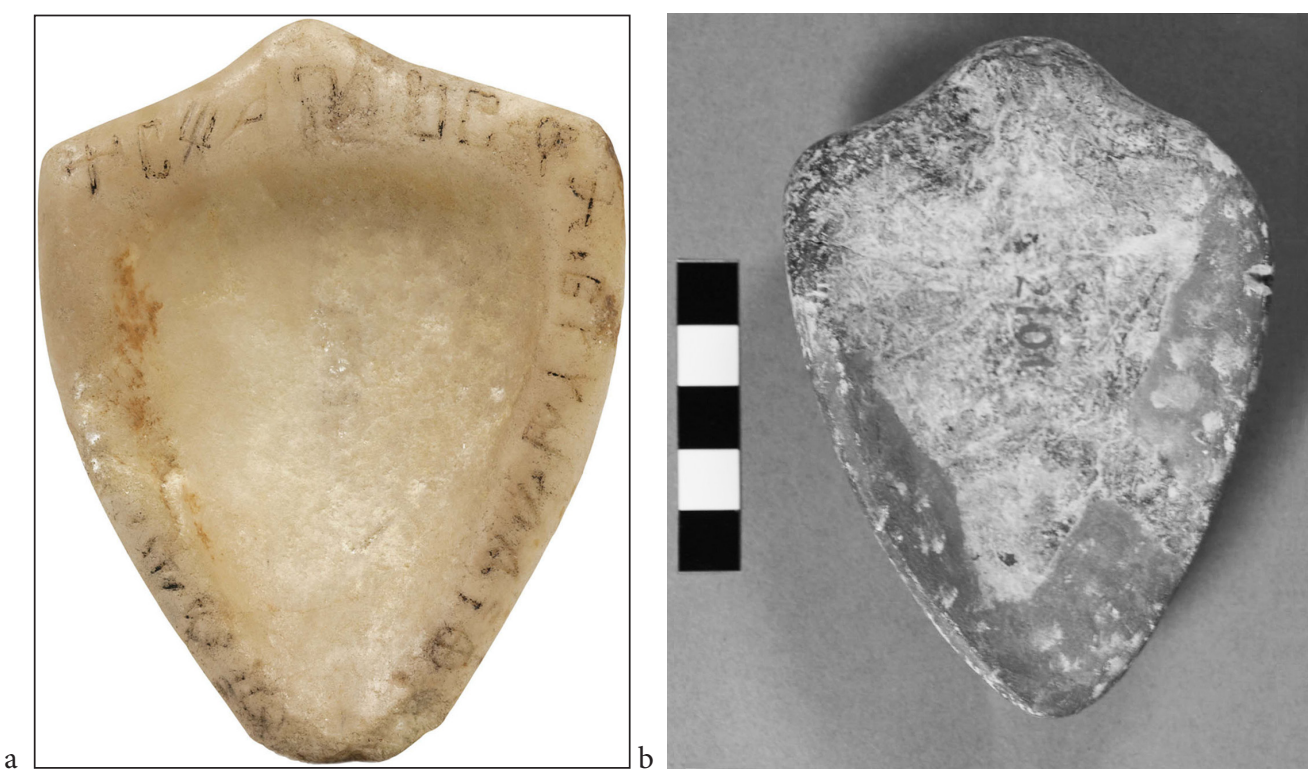

Figure 21: a) Alabaster ladle. Length: $6.5 \mathrm{~cm}$. TL Za 1 / HM L1545 from Troullos; b) Stone ladle. Length: $10.3 \mathrm{~cm}$. HM L2101 from the House of the Frescoes at Knossos.

reaching $31.8 \mathrm{~cm}$ (cf. Lebessi and Muhly 1990: 330-331, figs 19-20; Muhly in Muhly and Olivier 2008: 200, n. 15). Yet, the choice of adding an inscription to a libation table probably marked specific Syme votaries as "privileged individuals who could communicate directly with the divine" (Muhly in Muhly and Olivier 2008: 200-201). This suggestion could, in turn, corroborate the hypothesis that inscribed examples from this sanctuary and elsewhere contain personal names (Duhoux 1992: 81; Facchetti 1999: 130; Olivier in Muhly and Olivier 2008: 217).

Material qualities, such as shape and the proportions of the tops of the libation tables, may have influenced the placement of the inscriptions, given that the diameter of the cavity and the width of the raised collar and flat rim vary from piece to piece. For example, the inscription was placed on the vertical shoulder of libation table SY Za 9 due to its narrow rim (Olivier in Muhly and Olivier 2008: 213). In the case of the square example from Apodoulou AP Za 1 / HM L2478 (Figure 18a-b), which consisted of two separate pieces, the carving of the inscription around the sides of the top piece was the most obvious choice. But even the most common practice of aligning the 
inscription horizontally around the sides may reflect intentionality (Figure 19). The location of the formula in this case may relate to the wish to enable the participants in the ceremonial performance to see the inscription. The alternative location, on the top surface surrounding the cavity of the libation table (e.g. PK Za 8, 14-17, PS Za 1, VRY Za 1, IO Za 9, 15, SY Za 2), may indicate that the inscription was meant to be seen, or read, only by the person performing the rites (cf. Olivier in Muhly and Olivier 2008: 204). These patterns in the arrangement of the formula emphasise, in my opinion, the personal involvement of the votaries themselves in the offerings.

The desire for competitive display through the use of writing and, probably, through projecting one's identity is also manifested by the clay female statuette PO Zg 1 / HM P27663 from a later domestic context at Poros (Dimopoulou et al. 1993: 519-521, fig. 8). Here the libation formula has been adjusted to fit the available graphic space, being painted along the conical skirt of the statuette. A similar wish for competitive display may be evidenced through the offering of the miniaturised versions of stone votive vessels, which may have been used for the offering of precious liquids (Faure 1992: 95). As has been argued for similar examples from the peak sanctuary of Ioukhtas / Alonaki (Karetsou 1987: 86), the shape of these miniature vessels may evoke earlier forms. The inscriptions, positioned along the sides (e.g. IO Za 2 / HM L3557, IO Za 6 / HM L3785; cf. Figure 20a-b) or around the rim (e.g. TL Za 1 / HM L1545; cf. Figure 21a) appear to imitate the larger inscribed prototypes. The votaries claimed their right to address the divine element, but the inscription would only be visible on close inspection, such as when the vessel was held in the hand; alternatively, knowledge that writing was present and exclusive was probably all that mattered to the votaries. However, some of the inscriptions on the miniatures possibly included personal names (Facchetti 1999: 131; Monti 2005: 22), such as the stone cup IO Za 6 from Ioukhtas / Alonaki (Figure 20b) and the alabaster heart-shaped ladle TL Za 1 from Archanes / Troullos (Figure 21a). The signs on the latter were carved and also differentiated from the background with added colour.

It is also worth considering that the small size and weight of the miniaturised forms from Ioukhtas could be due to practical reasons, such as ease of transport along the long route to the peak of the Ioukhtas mountain. Nevertheless, ladles are also more commonly found in ritual contexts at settlements (Warren 1969: 49), as for example the aforementioned ladle from Archanes / Troullos (Figure 21a), the two similar stone ladles HM L2101 (Figure 21b) and HM L2102 from the House of the Frescoes at Knossos (Platon 1954: 444; Warren 1969: 49, fig. P289) as well as a small steatite vessel with two spoon-shaped hollows from Hogarth's House A at Gypsades (Hogarth 1899-1900: 73, fig. 13). Nonetheless, the marked concentration of inscribed and uninscribed miniature libation tables and cups in the wider region of Archanes (Ioukhtas and Troullos) and nearby Knossos probably reflects a local practice and the existence of a specialised workshop.

\section{Conclusions}

Symbolic behaviour is embodied in the regulation of social relationships through the use of Minoan writing on various material surfaces. This study has shown that the modes of display of the two Minoan scripts followed different paths. It is evident that captions, so popular in Near Eastern art, were probably never used in Minoan art. The display of the developed Hieroglyphic script of the MM IIB period was mostly dictated by a standardised administrative practice. The spatial organisation of script signs on the surface of the three- and four-sided prismatic seals enabled the latter to function as hierarchical devices, which could supplement or, even, substitute writing by making impressions on clay documents. Based on present evidence, we cannot assert whether the 'decorative' signs carved on Hieroglyphic seals represented writing that corresponded to spoken language. Non-verbal visualisations must have been more crucial to thought 
for the Minoans than we are able to understand presently, as shown particularly by the example of the 'Archanes Script Group' seals. I would like to suggest tentatively that the solitary pictorial signs first appearing on them were understood as semasiographic codes. These codes probably stemmed from the emblematic use of Minoan seal devices at least from the late Prepalatial period. During the transition to the Protopalatial period, the borrowed symbolism of the zoomorphic or anthropomorphic seals and those recalling amulets may derive from a sophisticated manipulation of related Egyptian forms of display and ideology (cf. e.g. Baines 2004).

The integration of the earliest script ('Archanes script') into three-dimensional seals and its interaction with image may have further fostered the pictorial character of the Hieroglyphic signs. The earliest seals that bear the standardised 'Archanes formula' were possibly aimed at projecting a message of restricted use and embodied new notions of ownership among the bearers of common uninscribed seals. Thus, they might have reflected a separate grouping within the Archanes community. Whether or not they symbolised the connection of specific elites with a supernatural element, as has been proposed by Sbonias (1995: 133), the management of a symbolic resource such as writing certainly was a key feature of social competition. Furthermore, the standardisation of the shape of the inscribed prismatic seals within the subsequent Protopalatial MM II glyptic tradition points to the establishment of social groupings and / or institutions with specific codes of communication during this period. The attestation of isolated impressions of MM II hieroglyphic seals in the Neopalatial Ayia Triada and Zakros administrative assemblages (CHIC: 30 ) supports the hypothesis that some of these seals may have functioned as hereditary symbolic devices, even after the Hieroglyphic script had ceased to be used.

During the Neopalatial period, individuals and groups of varying social status approached the production of Linear A and the use of the inscribed surfaces in different ways, allowing us to ascertain how the latter influenced the way knowledge was conveyed and perceived. Based on the evidence available, Linear A was not employed on monuments of public display, as was the case with Egyptian hieroglyphs. If it was felt necessary to communicate standardised narratives to multiple individuals simultaneously, other mechanisms must have been used. Portable objects inscribed in Linear A and made from different materials were commissioned for various reasons. An analytical focus on alignment and directionality has helped to make inferences about the "cultural biography" (Kopytoff 1986) of small-scale inscribed artefacts from costly materials, such as silver or gold hair pins and the gold Mavrospelio ring. These objects seem to have initially served an exclusive role for their owners in life, and were then buried with the deceased in order to serve him / her in the hereafter. If they were indeed produced by literate artisans, they could also reflect participation in a particular social group with access to symbolic resources, such as the secrets of metallurgy and writing. The removal of the pins from circulation through their deposition within elite burials possibly was a mechanism for maintaining their exclusive associations.

A ceremonial use of Linear A is documented beyond doubt by the formulaic inscriptions on Neopalatial stone libation vessels. The large inscribed libation tables from extra-urban sanctuaries were probably used for ritualised offering in the context of food and drink consumption. At the same time, they might have served as means of conspicuous display by the votaries. The possibility that some inscriptions contained personal names suggests that the votaries intended to show competitive generosity by declaring their association with the dedication. This intention is more evident in the case of the miniaturised versions of votives with inscriptions of a micrographic character. I suggest that these miniatures were produced with the aim of addressing an initiated group of participants in the rites, who adhered to a certain value code. Consequently, they may even legitimate claims of personal participation in the religious practice.

Last but not least, the role that the scale of writing played in imposing authority should be at the core of a material practice approach. On the basis of our analysis, it is possible to suggest that the micrographic character of the inscriptions multiplied the symbolic meaning of small ritual 
or prestige artefacts. In cases of display events, such as cult activities in the sanctuaries or burial deposition rituals, knowledge that writing was present, meaningful and exclusive would probably have mattered more for the social agents than the specific content of the inscription (cf. Baines 2004: 152). In another context, the sacred cave at Arkalochori, the hoarding of the two miniature, inscribed double axes could have been both a symbolic act and an ideal way to symbolically 'store' precious metals.

\section{Acknowledgements}

I am grateful to the organisers of the conference - Kathryn Piquette and Ruth Whitehouse and also to the anonymous reviewers, as well as to Dr A. Karnava, Dr P. Muhly, Dr V. Petrakis, Dr G. Rethemiotakis and Dr J. Smith for their valuable suggestions on the first draft of this paper. Special thanks are due to Dr C. Stray who read the latter and corrected the English. The final draft was written in the fall of 2011 during my S. Seeger Research Fellowship at the Center for Hellenic Studies, Princeton University. Photographs 2-4 and 7-21 are reproduced courtesy of the Heraklion Museum - Archaeological Receipts Fund.

\section{Abbreviations}

$\mathrm{BM}=$ British Museum inventory number

CMS = Corpus der Minoischen und Mykenischen Siegel

CMS II.1 = Platon, N. 1969. Corpus der Minoischen und Mykenischen Siegel. Iraklion Archäologisches Museum. Band II, Teil 1: Die Siegel der Vorpalastzeit. Berlin: Gebr. Mann Verlag.

CMS II.3 = Platon, N. and Pini, I. 1984. Corpus der Minoischen und Mykenischen Siegel. Iraklion Archäologisches Museum. Band II, Teil 3: Die Siegel der Neupalastzeit. Berlin: Gebr. Mann Verlag. CMS II.8 = Gill, M. A. V., Müller, W. and Pini, I. 2002. Corpus der Minoischen und Mykenischen Siegel: Iraklion. Archäologisches Museum. Band II, Teil 8,1: Die Siegelabdrücke von Knossos. Mainz am Rhein: Verlag Philipp von Zabern.

CMS III.1 = Müller, W. and Pini, I. 2007. Corpus der Minoischen und Mykenischen Siegel: Iraklion. Archäologisches Museum. Mainz am Rhein: Verlag Philipp von Zabern.

CMS VI = Hughes-Brock, H. and Boardman, J. 2009. Corpus der Minoischen und Mykenischen Siegel: Oxford. The Ashmolean Museum. Mainz am Rhein: Verlag Philipp von Zabern.

CMS VII = Kenna, V. E. G. 1967. Corpus der Minoischen und Mykenischen Siegel. Die englischen Museen II. Band VII. Berlin: Gebr. Mann Verlag.

$\mathrm{HM}=$ Heraklion Museum inventory number

\section{Notes}

${ }^{1}$ The term 'morpheme' denotes the smallest and most basic grammatical unit (Coulmas 2003: 33).

${ }^{2}$ Godart and Olivier (1996) numbers preceded by the symbol \# refer to hieroglyphic documents. For the plain numbers that are conventionally used to denote the hieroglyphic signs, cf. Olivier and Godart 1996: 17, tableau des signes standardisés de l'hiéroglyphique crétois (MNAMON 2009-2012). With regard to the directionality of the signs on hieroglyphic seals, the transcription in Olivier and Godart (1996) follows the way signs were engraved on the seals and not their positive impressions on clay. 
${ }^{3}$ Hieroglyphic continued to be used at Malia during the beginning of the Neopalatial period (MM III), as shown by the documents of the 'Dépôt Hiéroglyphique' in the palace (Olivier and Godart 1996: 28, n. 11).

4 'Medallions' and 'crescents' were hanging documents inscribed in Cretan Hieroglyphic; they were used as primary documents from which data was transferred to four-sided clay bars, cf. Tsipopoulou and Hallager 2010: 74-79, 84-86, 258, and 12-14 (on types of hieroglyphic documents).

${ }^{5}$ This inference is supported by the three MM IB noduli of the Knossian Deposit A, which were stamped by an ivory / bone seal depicting an agrimi; Weingarten (2007: 135) interprets them as laisser-passer or private receipts.

${ }^{6}$ By MM IB, a transference of visual symbols from inscribed seals to pots may have taken place as suggested by Haggis (2007: 763-766) on the basis of the 'Lakkos deposit' from Petras.

7 An early clay model of an Egyptian sistrum has been excavated in Archanes Burial Building 9 (Sakellarakis and Sapouna-Sakellaraki 1997: 329; Sapouna 2001: 267).

\section{References}

Alexiou, S. and Brice, W. C. 1972. A Silver Pin from Mavro Spelio with an Inscription in Linear A: Her. Mus. 540. Kadmos 11(2): 113-124. DOI: http://dx.doi.org/10.1515/kadm.1972.11.2.113

Alexiou, S. and Brice, W. C. 1976. A Silver Pin from Platanos with an Inscription in Linear A: Her. Mus. 498. Kadmos 15(1): 18-27. DOI: 10.1515/kadm.1976.15.1.18

Anastasiadou, M. 2011. The Middle Minoan Three-Sided Soft Stone Prism: A study of style and iconography (CMS Beiheft 9). Mainz: Verlag Philipp von Zabern.

Aruz, J. 2000. Artistic Change and Cultural Exchange: The glyptic evidence. In Pini, I. (ed.), Minoisch-Mykenische Glyptik: Stil, Ikonographie, Funktion. V. Internationales Siegel-Symposium Marburg, 23.-25. September 1999 (CMS Beiheft 6). Berlin: Gebr. Mann Verlag, 1-13.

Baines, J. 2004. The Earliest Egyptian Writing: Development, context, purpose. In Houston, S. D. (ed.), The First Writing: Script Invention as History and Process. Cambridge: Cambridge University Press, 150-189.

Banou, E. 2001. 190a-b. Signed cups. In Karetsou, A., Andreadaki-Vlazaki, M. and Papadakis, N. (eds), Crete - Egypt: Three thousand years of cultural links. Catalogue. Herakleion: Hellenic Ministry of Culture, 196.

Bennet, J. 2008. Now You See It; Now You Don't! The disappearance of the Linear A script on Crete. In Baines, J., Bennet, J. and Houston, S. D. (eds), The Disappearance of Writing Systems: Perspectives on literacy and communication. London: Equinox, 1-29.

Boulotis, C. 2008. The Art of Cretan Writing. In Andreadaki-Vlazaki, M., Rethemiotakis, G. and Dimopoulou-Rethemiotaki, N. (eds), From the Land of the Labyrinth: Minoan Crete, 3000-1100 B.C. Essays. New York: Alexander S. Onassis Public Benefit Foundation (USA), 67-78.

Branigan, K. 1970. The Tombs of Mesara: A study of funerary architecture and ritual in Southern Crete, 2800-1700 B.C. London: Gerald Duckworth.

Brice, W. C. 1990. Notes on the Cretan Hieroglyphic Script. Kadmos 29(1): 1-10. DOI: http:// dx.doi.org/10.1515/kadm.1990.29.1.1

Brice, W. C. 1997. Notes on the Cretan Hieroglyphic Script. Kadmos 36(2): 93-96. DOI: http:// dx.doi.org/10.1515/kadm.1997.36.2.93

Cameron, S. A. 1968. The Painted Signs on Fresco Fragments from the "House of the Frescoes". Kadmos 7: 45-64.

Catling, H. W. and Cavanagh, C. 1976. Two Inscribed Bronzes from the Menelaion, Sparta. Kadmos 15: 145-157. 
Chandler, D. 2007. Semiotics: The basics ( $2^{\text {nd }}$ ed.). London and New York: Routledge.

Cooper, J. S. 2004. Babylonian Beginnings: The origin of the cuneiform writing system in comparative perspective. In Houston, S. D. (ed.), The First Writing. Script invention as history and process. Cambridge: Cambridge University Press, 71-99.

Coulmas, F. 2003. Writing Systems: An introduction to their linguistic analysis. Cambridge: Cambridge University Press.

Dahl, J. 2009. The Marks of Early Writing. Paper delivered at conference, "Writing as Material Practice: Substance, surface, and medium" held on 15-17 May 2009 at the Institute of Archaeology, University College London.

Dant, T. 2005. Materiality and Society. Maidenhead: Open University Press.

Dimopoulou, N., Olivier, J-P. and Rethemiotakis, G. 1993. Une statuette en argile avec inscription en Linéaire A de Poros/Irakliou. Bulletin de Correspondance Hellénique 117: 501-521. DOI: http://dx.doi.org/10.3406/bch.1993.4657

Dreyer, G. 1998. Umm el-Qaab I: Das prädynastische Königsgrab U-j und seine frühen Schriftzeugnisse (Archäologische Veröffentlichungen 86). Mainz am Rhein: Verlag Philipp von Zabern.

Driessen, J. 1994. A Fragmentary Linear A Inscription from Petsophas, Palaikastro (PK ZA 20). Kadmos 33(2): 149-152. DOI: http://dx.doi.org/10.1515/kadm.1994.33.2.149

Drucker, J. and McGann, J. 2001. Images as the Text: Pictographs and pictographic rhetoric. Information Design Journal 10(2): 95-106.

Duhoux, Y. 1992. Variations morphosyntaxiques dans les texts votifs Linéaires A. Cretan Studies 3: 65-88.



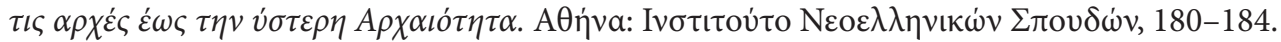

Evans, A. 1909. Scripta Minoa: The written documents of Minoan Crete with special reference to the archives of Knossos, Volume 1: The Hieroglyphic and Primitive Linear Classes. Oxford: Clarendon Press.

Evans, A. 1921. The Palace of Minos at Knossos: Volume 1. The Neolithic and Early and Middle Minoan Ages. London: Macmillan and Co., Ltd.

Facchetti, G. M. 1999. Non-Onomastic Elements in Linear A. Kadmos 38: 121-136.

Faure, P. 1992. ATANU, ATANOWO, ATANUPI. Cretan Studies 3: 89-95.

Forsdyke, E. J. 1927. The Mavro Spelio Cemetery at Knossos. Annual of the British School at Athens 28: 243-296. DOI: http://dx.doi.org/10.1017/S0068245400011187

Gelb, I. 1952. A Study of Writing. Chicago: University of Chicago Press.

Gell, A. 1998. Art and Agency: An anthropological theory. Oxford: Clarendon Press.

Godart, L. 1999. Lécriture d’Arkhanès: Hiéroglyphique ou Linéaire A? In Betancourt, P. P., Karageorghis, V., Laffineur, R. and Niemeier, W.-D. (eds), Meletemata: Studies in Aegean archaeology presented to Malcolm H. Wiener as he enters his $65^{\text {th }}$ year. Volume 1 (Aegaeum 20). Liège: Université de Liège, Histoire de l'art et archéologie de la Grèce antique and Austin, TX: University of Texas at Austin, Program in Aegean Scripts and Prehistory, 299-302.

Godart, L. and Olivier, J.-P. 1982. Recueil des inscriptions en Linéaire A. Volume 4. Paris: Geuthner dépositaire.

Godart, L. and Olivier, J.-P. 1976. Sur l'épingle de Mavro Spelio. Bulletin de Correspondance Hellénique 100: 309-314. DOI: http://dx.doi.org/10.3406/bch.1976.2047

Graves-Brown, P. M. (ed.) 2000. Matter, Materiality and Modern Culture. London: Routledge.

Grumach, E. 1968. The Minoan Libation Formula - Again. Kadmos 7: 7-26.

Grumach, E. and Sakellarakis, I. A. 1966. Die neuen Hieroglyphensiegel vom Phourni (Archanes) I. Kadmos 5(2): 109-114. DOI: http://dx.doi.org/10.1515/kadm.1966.5.2.109

Haas, C. 1996. Writing Technology: Studies on the materiality of literacy. Mahwah, NJ: Lawrence Earlbaum Associates. 
Haggis, D. G. 2007. Stylistic Diversity and Diacritical Feasting at Protopalatial Petras: A preliminary analysis of the Lakkos deposit. American Journal of Archaeology 111(4): 715-775. DOI: http://dx.doi.org/10.3764/aja.111.4.715

Hallager, E., Papadopoulou, E. and Tzachili, I. 2011. VRY S (4/4) 01 - The first hieroglyphic inscription from western Crete. Kadmos 50: 63-174.

Harris, R. 1986. The Origin of Writing. La Salle, IL: Open Court Press.

Harris, R. 1995. Signs of Writing. London: Routledge.

Hill-Boone, E. 2004. Beyond Writing. In Houston, S. D. (ed.), The First Writing: Script invention as history and process. Cambridge: Cambridge University Press, 313-348.

Hogarth, D. G. 1899-1900. Knossos Summary Report of the Excavations in 1900: II. Early town and cemeteries. Annual of the British School at Athens 6: 70-85.

Hood, S. 1997. A Monumental Linear A Inscription from Knossos. Annual of the British School at Athens 36: 111-117.

Jasink, A. M. 2009. Cretan Hieroglyphic Seals: A new classification of symbols and ornamental/filling motifs (Biblioteca di "Pasiphae" 9). Pisa-Roma: Fabrizio Serra Ed.

Jones, A. 2007. Memory and Material Culture. Cambridge and New York: Cambridge University Press. DOI: http://dx.doi.org/10.1017/CBO9780511619229

Kahl, J. 1994. Das System der ägyptischen Hieroglyphenschrift in der 0.-3. Dynastie. Wiesbaden: Harrassowitz.

Karetsou, A. 1987. Duo nees epigrafes Grammikis Graphis A apo to iero koryfis Ioukhta. In Kastrinaki, L., Orphanou, G. and Giannadakis, N. (eds), Eilapine: tomos timitikos yia ton kathiyiti Nikolao Platona. Volume 1. Vikelea Dimotiki Vivliothiki, Heraklion, 85-91.

Karnava, A. 2000. The Cretan Hieroglyphic Script of the Second Millennium BC: Description, analysis function and decipherment perspectives. Unpublished PhD dissertation, Université Libre de Bruxelles.

Karytinos, A. 1998. Sealstones in Cemeteries: A display of social status? In Branigan, K. (ed.), Cemetery and Society in the Aegean Bronze Age (Sheffield Studies in Aegean Archaeology 1). Sheffield: Sheffield Academic Press, 78-86.

Kenna, V. E. G. 1967. Corpus den Minoischen und Mykenischen Siegel Band 7: Die Englischen Museen 2. Berlin: Verlag Gebr. Mann.

Knappett, C. 2004. The Affordances of Things: A post-Gibsonian perspective on the relationality of mind and matter. In DeMarrais, E., Gosden, C. and Renfrew, C. (eds), Rethinking Materiality: The engagement of mind with the material world. Cambridge: McDonald Institute Monographs, 43-51.

Knappett, C. 2005. Thinking Through Material Culture: An interdisciplinary perspective. Philadelphia, PA: University of Pennsylvania Press.

Knappett, C. 2008. The Neglected Networks of Material Agency: Artefacts, pictures and texts. In Knappett, C. and Malafouris, L. (eds), Material Agency: Towards a non-anthropocentric approach. New York, NY: Springer US, 139-156. DOI: http://dx.doi.org/10.1007/978-0-387-74711-8_8

Krzyszkowska, O. 2005. Aegean Seals: An introduction (BICS Supplement 85). London: Institute of Classical Studies.

Krzyszkowska, O. 2012. Seals from the Petras Cemetery: A preliminary overview. In Tsipopoulou, M. (ed.), Petras: 25 years of excavations and studies. Acts of a two-day conference held at the Danish Institute at Athens, 9-10 October 2010 (Monographs of the Danish Institute at Athens Volume 16). Århus: Århus University Press, 145-156.

Lebessi, A. and Muhly, P. 1990. Aspects of Minoan Cult: Sacred enclosures: The evidence from the Syme Sanctuary (Crete). Archäologischer Anzeiger 1990: 315-336.

Lebessi, A., Muhly, P. and Olivier, J.-P. 1995. An Inscription in the Hieroglyphic Script from the Syme Sanctuary, Crete (SY Hf 01). Kadmos 34: 63-77. DOI: http://dx.doi.org/10.1515/ kadm.1995.34.1.63 
MacDonald, C. F. 2007. The Small Finds. In MacDonald, C. F. and Knappett, C. (eds), Knossos Protopalatial Deposits in Early Magazine A and the South-west Houses (The British School at Athens, Supplementary Volume 41). Oxford and Northampton: The British School at Athens, $121-131$.

Marinatos, S. 1962. Zur Frage der Grotte von Arkalochori. Kadmos 1(2): 87-94. DOI: http:// dx.doi.org/10.1515/kadm.1962.1.2.87

Michailidou, A. 2003. Measuring Weight and Value in Bronze Age Economies in the Aegean and the Near East: A discussion on metal axes of no practical use. In Foster, K. P. and Laffineur, R. (eds), METRON: Measuring the Aegean Bronze Age: Proceedings of the $9^{\text {th }}$ International Aegean Conference, New Haven, Yale University, 18-21 April 2002 (Aegaeum 24). Liège: Université de Liège, Histoire de l'art et archéologie de la Grèce antique and Austin, TX: University of Texas at Austin, Program in Aegean Scripts and Prehistory, 301-314.

Militello, P. 2000. "L'archivio di cretule" del vano 25 e un nuovo sigillo da Festòs. In Perna, M. (ed.), Administrative Documents in the Aegean and Their Near Eastern Counterparts: Proceedings of the International Colloquium, Naples, February 29-March 2, 1996. Torino: Paravia Scriptorium, 221-243.

Militello, P. 2002. Amministrazione e contabilità a Festòs, II: Il contesto archeologico dei documenti palatini. Creta Antica 3: 51-91.

MNAMON: Portal for Ancient Writing Systems in the Mediterranean: A critical guide to electronic resources 2009-2012. Cretan Hieroglyphics: Examples of writing. Laboratorio Informatico per le Lingue Antiche. http://lila.sns.it/mnamon/index.php?page=Esempi\&id=35\&lang= en\&PHPSESSID=2a0a7e1b9d978d031dfa742731f1b9e7 [accessed 1 June 2012].

Monti, O. 2005. Considérations sur quelques termes des textes votifs linéaires A. Kadmos 44(1-2): 19-22. DOI: http://dx.doi.org/10.1515/KADM.2005.005

Muhly, P. and Olivier, J.-P. 2008. Linear A Inscriptions from the Syme Sanctuary, Crete. Archaiologike Ephemeris 2008: 197-223.

Nuessel, F. H. 2006. Pictography: Semiotic approaches. In Brown, K. (ed.) Encyclopedia of Language and Linguistics ( $2^{\text {nd }}$ ed.). Oxford: Elsevier, 591-599.

Olivier, J.-P. 1989a. The Possible Methods in Deciphering the Pictographic Cretan Script. In Duhoux, Y., Palaima, T. G. and Bennet, J. (eds), Problems in Decipherment (Bibliothèque des cahiers de l'Institut de Linguistique de Louvain 9). Peeters: Louvain-La-Neuve, 39-58.

Olivier, J.-P. 1989b. Le "Disque de Mokhlos": une nouvelle inscription en linéaire A sur un poids de plomb, HM 83/MO Zf 1. Kadmos 28(1-2): 137-145. DOI: http://dx.doi.org/10.1515/ kadm.1989.28.1-2.137

Olivier, J.-P. 1990. The Relationship Between Inscriptions on Hieroglyphic Seals and Those Written on Archival Documents. In Palaima, T. G. (ed.), Aegean Seals, Sealings and Administration: Proceedings of the NEH-Dickson Conference of the Program in Aegean Scripts and Prehistory of the Department of Classics, University of Texas at Austin, January 11-13, 1989 (Aegaeum 5). Liège: Université de Liège, Histoire de l'art et archéologie de la Grèce antique and Austin, TX: University of Texas at Austin, Program in Aegean Scripts and Prehistory, $11-19$.

Olivier, J.-P. 1995. Les sceaux avec des signes hiéroglyphiques: Que lire? Une question de bon sens. In Pini, I. and Poursat, J.-C. (eds), Sceaux Minoens et Mycéniens (CMS Beiheft 5). Berlin: Gebr. Mann Verlag, 169-181.

Olivier, J.-P. 2000. Les sceaux avec des inscriptions hiéroglyphiques. Comment comprendre? In Perna, M. (ed.), Administrative Documents in the Aegean and Their Near Eastern Counterparts: Proceedings of the International Colloquium, Naples, February 29-March 2, 1996. Torino: Paravia Scriptorium, 141-168.

Olivier, J.-P. and Godart, L. (eds) 1996. Corpus Hieroglyphicarum Inscriptionum Cretae (Études Crétoises 31). Paris: De Boccard. 
Olivier, J.-P., Godart, L. and Laffineur, R. 1981. Une épingle minoenne en or avec inscription en Linéaire A. Bulletin de Correspondance Hellénique 105(1): 3-25. DOI: http://dx.doi. org/10.3406/bch.1981.1928

Peirce, C. S. 1931. Collected Papers of Charles Sanders Peirce, Volume 1: Principles of philosophy (Edited by C. Hartshorne, P. Weiss and A. W. Burks). Cambridge, MA: Harvard University Press.

Pelon, O. 1980. Le palais de Malia V.2 (Études crétoises 25). Paris: P. Geuthner.

Perna, M. 1995. The Roundels of Phaistòs. Kadmos 34: 103-122. DOI: http://dx.doi.org/10.1515/ kadm.1995.34.2.103

Phillips, J. 2008a. Aegyptiaca on the Island of Crete in Their Chronological Context: A critical review. Volume 1. Wien: Verlag der Österreichischen Akademie der Wissenschaften.

Phillips, J. 2008b. Aegyptiaca on the Island of Crete in Their Chronological Context: A critical review. Volume 2. Wien: Verlag der Österreichischen Akademie der Wissenschaften.

Phillips, J. 2010. Non-Administrative Glyptic Relations Between the Aegean and Egypt. In Müller, W. (ed.), Die Bedeutung der minoischen und mykenischen Glyptik (CMS Beiheft 8). Mainz am Rhein: Verlag Philipp von Zabern, 309-323.

Platon, N. 1954. Ta minoika oikiaka hiera. Kretika Chronika 8: 428-483.

Poursat, J.-C. 1996. Fouilles exécutées à Malia: Le quartier Mu 3. Artisans minoens. Les maisonsateliers du quartier $M u$ (Études crétoises 32). Paris: P. Geuthner.

Poursat, J.-C. 2000. Les sceaux hiéroglyphiques dans l'administration minoenne: Usage et fonction. In Perna, M. (ed.), Administrative Documents in the Aegean and Their Near Eastern Counterparts. Proceedings of the International Colloquium, Naples, February 29-March 2, 1996. Torino: Paravia Scriptorium, 187-191.

Raison, J. 1963. Les coupes de Cnossos avec inscriptions en Linéaire A. Kadmos 2: 17-26.

Raison, J. and Pope, M. 1981. Corpus transnuméré du linéaire A (Bibliotheque des Cahiers de l'Institut de Linguistique de Louvain 18). Louvain-La-Neuve: Cabay.

Relaki, M. 2009. Rethinking Administration and Seal Use in Third Millennium Crete. Creta Antica 10(2): 353-372.

Robertson, J. S. 2004. The Possibility and Actuality of Writing. In Houston, S. D. (ed.), The First Writing: Script invention as history and process. Cambridge: Cambridge University Press, $16-38$.

Sakellarakis, Y. and Sapouna-Sakellaraki, E. 1997. Archanes: Minoan Crete in a new light, 2 volumes. Athens: Ammos Publications.

Sapouna, P. 2001. 265. Sistrum. In Karetsou, A., Andreadaki-Vlazaki, M. and Papadakis, N. (eds), Crete - Egypt: Three thousand years of cultural links: Catalogue. Herakleion: Hellenic Ministry of Culture, 267.

Sbonias, K. 1995. Frühkretische Siegel. Ansätze für eine Interpretation der sozial-politischen Entwicklung auf Kreta während der Frühbronzezeit (British Archaeological Reports International Series 620). Oxford: Oxbow Books.

Sbonias, K. 1999. Social Development, Management of Production, and Symbolic Representation in Prepalatial Crete. In Chaniotis, A. (ed.), From Minoan Farmers to Roman Traders: Sidelights on the economy of ancient Crete. Stuttgart: Franz Steiner Verlag, 25-51.

Sbonias, K. 2010. Diversity and Transformation: Looking for meanings in the Prepalatial seal consumption and use. In Müller, W. (ed.), Die Bedeutung der Minoischen und Mykenischen Glyptik. 6. Internationales Siegel-Symposium aus Anlass des 50 jährigen Bestehens des CMS Marburg, 9.-12. Oktober 2008. Mainz am Rhein: Verlag Philipp von Zabern, 349-362.

Schmandt-Besserat, D. 2007. When Writing Met Art: From symbol to story. Austin: University of Texas Press.

Schoep, I. 1994. Ritual, Politics and Script on Minoan Crete. Aegean Archaeology 1: 7-25. 
Schoep, I. 2002a. The Administration of Neopalatial Crete: A critical assessment of the Linear A tablets and their role in the administrative process (Minos Supplement 17). Salamanca: Ediciones Universidád de Salamanca.

Schoep, I. 2002b. The State of the Minoan Palaces or the Minoan Palace State? In Driessen, J, Schoep, I. and Laffineur, R. (eds), Monuments of Minos: Rethinking the Minoan palaces: Proceedings of the international workshop "Crete of the hundred Palaces?", held at the Université Catholique de Louvain, Louvain-la-Neuve, 14-15 December 2001 (Aegaeum 23). Liège: Université de Liège, Histoire de l'art et archéologie de la Grèce antique and Austin, TX: University of Texas at Austin, Program in Aegean Scripts and Prehistory, 15-33.

Schoep, I. 2002c. Social and Political Organisation on Crete in the Proto-palatial Period: The case of Malia in MM II. Journal of Mediterranean Archaeology 15(2): 102-125.

Schoep, I. 2006. Looking Beyond the First Palaces: Elites and the agency of power in EM IIIMM II Crete. American Journal of Archaeology 110(1): 37-64. DOI: http://dx.doi.org/10.3764/ aja.110.1.37

Schoep, I. 2007. The Inscribed Document. In MacDonald, C. F. and Knappett, C. (eds), Knossos Protopalatial Deposits in Early Magazine A and the South-west Houses (The British School at Athens, Supplementary Volume 41). Oxford and Northampton: The British School at Athens, 131-134.

Tsipopoulou, M. and Hallager, E. 2010. The Hieroglyphic Archive at Petras, Siteia (Monographs of the Danish Institute at Athens Volume 9). Århus: Aarhus University Press.

Warren, P. 1969. Minoan Stone Vases. Cambridge: Cambridge University Press.

Watrous, L. V. 1994. Review of Aegean Prehistory III: Crete from earliest Prehistory through the Protopalatial Period. American Journal of Archaeology 98(4): 695-753. DOI: http://dx.doi. org/10.2307/506551

Weingarten, J. 1994. Sealings and Sealed Documents at Bronze Age Knossos. In Evely, D., HughesBrock, H. and Momigliano, N. (eds), Knossos: A labyrinth of history: Papers presented in honour of Sinclair Hood. Oxford: British School at Athens and Oxbow Books, 171-188.

Weingarten, J. 1995. Sealing Studies in the Middle Bronze Age III: The Minoan Hieroglyphic Deposits at Mallia and Knossos. In Pini, I. and Poursat, J.-C. (eds), Sceaux Minoens et Mycéniens (CMS Beiheft 5). Berlin: Gebr. Mann Verlag, 285-311.

Weingarten, J. 2007. Noduli, Sealings and a Weight from Deposits A and E. In MacDonald, C. F. and Knappett, C. (eds), Knossos Protopalatial Deposits in Early Magazine A and the South-west Houses (The British School at Athens, Supplementary Volume 41). Oxford and Northampton: The British School at Athens, 134-139.

Wilson, P. 2003. Hieroglyphs: A very short introduction. Oxford: Oxford University Press.

Younger, J. G. 1979. The Lapidary's Workshop at Knossos. Annual of the British School at Athens 74: $258-268$.

Younger, J. G. 1990. New Observations on Hieroglyphic Seals. Studi Micenei ed Egeo-Anatolici 28: 85-93.

Younger, J. G. 1999. The Cretan Hieroglyphic Script: A review article. Minos 31-32: 379-400.

Younger, J. G. 2002. Linear A Texts in Phonetic Transcription. Texts employing the "libation" formula in full or in part: http://www.people.ku.edu/ jyounger/LinearA/religioustexts.html\#part1 [Accessed 25 November 2013].

Yule, P. 1980. Early Cretan Seals: A study of chronology (Marburger Studien zur Vor- und Frühgeschichte 4). Mainz: Philipp von Zabern.

Zinna, A. 2011. The Object of Writing. Language Sciences 33(4): 634-646. DOI: http://dx.doi. org/10.1016/j.langsci.2011.04.034 